\title{
Intracellular Magnesium-Dependent Modulation of Gap Junction Channels Formed by Neuronal Connexin36
}

\author{
Nicolás Palacios-Prado, ${ }^{1}$ Gregory Hoge, ${ }^{1}$ Alina Marandykina, ${ }^{1,2}$ Lina Rimkute,,${ }^{1,2}$ Sandrine Chapuis, ${ }^{1}$ \\ Nerijus Paulauskas, ${ }^{1,2}$ Vytenis A. Skeberdis, ${ }^{2}$ John 0'Brien, ${ }^{3}$ Alberto E. Pereda, ${ }^{1}$ Michael V. L. Bennett, ${ }^{1}$ \\ and Feliksas F. Bukauskas ${ }^{1}$ \\ ${ }^{1}$ Dominick P. Purpura Department of Neuroscience, Albert Einstein College of Medicine, Bronx, New York 10461, 2Institute of Cardiology, Lithuanian \\ University of Health Sciences, LT-50009 Kaunas, Lithuania, and ${ }^{3}$ Department of Ophthalmology and Visual Science, University of Texas Medical School at \\ Houston, Houston, Texas 77030
}

Gap junction (GJ) channels composed of Connexin36 (Cx36) are widely expressed in the mammalian CNS and form electrical synapses between neurons. Here we describe a novel modulatory mechanism of $\mathrm{Cx} 36 \mathrm{GJ}$ channels dependent on intracellular free magnesium $\left(\left[\mathrm{Mg}^{2+}\right]_{\mathrm{i}}\right)$. We examined junctional conductance $\left(g_{\mathrm{j}}\right)$ and its dependence on transjunctional voltage $\left(V_{\mathrm{j}}\right)$ at different $\left[\mathrm{Mg}^{2+}\right]_{\mathrm{i}}$ in cultures of HeLa or N2A cells expressing Cx36. We found that $\mathrm{Cx} 36 \mathrm{GJs}$ are partially inhibited at resting $\left[\mathrm{Mg}^{2+}\right]_{\mathrm{i}}$. Thus, $g_{\mathrm{j}}$ can be augmented or reduced by lowering or increasing $\left[\mathrm{Mg}^{2+}\right]_{\mathrm{i}}$, respectively. Similar changes in $g_{\mathrm{j}}$ and $V_{\mathrm{j}}$-gating were observed using MgATP or $\mathrm{K}_{2} \mathrm{ATP}$ in pipette solutions, which increases or decreases $\left[\mathrm{Mg}^{2+}\right]_{i}$, respectively. Changes in phosphorylation of $\mathrm{Cx} 36$ or in intracellular free calcium concentration were not involved in the observed $\mathrm{Mg}^{2+}$-dependent modulation of $g_{\mathrm{j}}$. Magnesium ions permeate the channel and transjunctional asymmetry in $\left[\mathrm{Mg}^{2+}\right]_{\mathrm{i}}$ resulted in asymmetric $V_{\mathrm{j}}$-gating. The $g_{\mathrm{j}}$ of $\mathrm{GJs}$ formed of $\mathrm{Cx} 26, \mathrm{Cx} 32, \mathrm{Cx} 43, \mathrm{Cx} 45$, and $\mathrm{Cx} 47$ was also reduced by increasing $\left[\mathrm{Mg}^{2+}\right]_{\mathrm{i}}$, but was not increased by lowering $\left[\mathrm{Mg}^{2+}\right]_{\mathrm{i}}$; single-channel conductance did not change. We showed that $\left[\mathrm{Mg}^{2+}\right]_{\mathrm{i}}$ affects both open probability and the number of functional channels, likely through binding in the channel lumen. Finally, we showed that $\mathrm{Cx} 36$-containing electrical synapses between neurons of the trigeminal mesencephalic nucleus in rat brain slices are similarly affected by changes in $\left[\mathrm{Mg}^{2+}\right]_{\mathrm{i}}$. Thus, this novel modulatory mechanism could underlie changes in neuronal synchronization under conditions in which ATP levels, and consequently $\left[\mathrm{Mg}^{2+}\right]_{\mathrm{i}}$, are modified.

\section{Introduction}

Electrical synapses are specialized junctions between neurons formed by clusters of gap junction (GJ) channels that enable direct cell-to-cell transfer of electrotonic potential, signaling molecules, and metabolites. Each GJ channel is formed by two apposed hemichannels (aHCs), each of which is formed by six connexin $(\mathrm{Cx})$ subunits. Neurons in the adult brain, as well as insulin-secreting $\beta$-cells in the pancreas, express Cx36 (Condorelli et al., 1998; Söhl et al., 1998; Serre-Beinier et al., 2000). GJs composed of a single Cx isoform generally show a maximum junctional conductance $\left(g_{\mathrm{j}}\right)$ at transjunctional voltage $\left(V_{\mathrm{j}}\right)$ equal zero and a symmetric $g_{\mathrm{j}}$ decrease with increasing $V_{\mathrm{j}}$ of either polarity. The change in $g_{j}$ is attributed to the presence in each aHC of two $V_{\mathrm{j}}$-sensitive gates, a "fast" gate and a "slow" gate

Received June 12, 2012; revised Jan. 7, 2013; accepted Jan. 8, 2013.

Author contributions: N.P.-P., V.A.S., A.E.P., M.V.L.B., and F.F.B. designed research; N.P.-P., G.H., A.M., L.R., S.C., and F.F.B. performed research; J.O. contributed unpublished reagents/analytic tools; N.P.-P., G.H., A.M., L.R., S.C., N.P., and F.F.B. analyzed data; N.P.-P., G.H., V.A.S., J.O., A.E.P., M.V.L.B., and F.F.B. wrote the paper.

This work was supported by the National Institutes of Health Grants EY 12857 to J.0.; DC 011099 and R21NS 055726 to A.E.P.; NS 55363 to M.V.L.B.; and R01NS 072238 and R01HL 084464 to F.F.B. We thank Dr. Vytautas K. Verselis and Dr. Thaddeus A. Bargiello for helpful comments and discussions, and Angele Bukauskiene for excellent technical assistance. N.P.-P. is a Howard Hughes Medical Institute International Student Research Fellow.

The authors declare no competing financial interests.

Correspondence should be addressed to Feliksas F. Bukauskas, Department of Neuroscience, Albert Einstein College of Medicine, 1300 Morris Park Ave., Bronx, NY 10461. E-mail: feliksas.bukauskas@einstein.yu.edu.

DOI:10.1523/JNEUROSCI.2825-12.2013

Copyright $\odot 2013$ the authors $\quad 0270-6474 / 13 / 334741-13 \$ 15.00 / 0$
(Bukauskas and Weingart, 1994). Cx36-containing electrical synapses are expressed in many regions of the mammalian CNS, such as the trigeminal mesencephalic (MesV) nucleus, inferior olive, thalamus, hippocampus, cortex, and retina (Connors and Long, 2004), and are thought to promote neuronal synchronization and coordinated activity of various neuronal networks (Bennett and Zukin, 2004).

Normally, the intracellular concentration of free magnesium $\left(\left[\mathrm{Mg}^{2+}\right]_{\mathrm{i}}\right.$ ) is $\sim 10 \times$ lower than that of total magnesium (Grubbs, $2002)$; most of the $\mathrm{Mg}^{2+}$ is bound to ATP, and changes in cytosolic ATP concentration $\left([\mathrm{ATP}]_{\mathrm{i}}\right)$ produce opposite changes in $\left[\mathrm{Mg}^{2+}\right]_{\mathrm{i}}$ (Lüthi et al., 1999). Under physiological conditions, neuronal $[\mathrm{ATP}]_{\mathrm{i}}$ increases during glucose and lactate exposure (Ainscow et al., 2002), and when neuronal activity is reduced during sleep (Dworak et al., 2010). Conversely, ATP levels are reduced by increased neuronal activity during wake periods and hyperactivity (Dworak et al., 2010). Pathological conditions, such as hypoxia, ischemia, and seizures, produce long-lasting depletion of $[\mathrm{ATP}]_{\mathrm{i}}$ and elevated $\left[\mathrm{Mg}^{2+}\right]_{\mathrm{i}}$ (Murphy et al., 1989; Headrick and Willis, 1991; Helpern et al., 1993). In contrast, traumatic brain injury results in a $\sim 50 \%$ reduction in $\left[\mathrm{Mg}^{2+}\right]_{\mathrm{i}}$ for several days (Cernak et al., 1995; Heath and Vink, 1996; Suzuki et al., 1997). Resting brain $\left[\mathrm{Mg}^{2+}\right]_{\mathrm{i}}$ is also reduced in patients with neurological diseases, such as Parkinson's (Barbiroli et al., 1999) and Alzheimer's (Andrási et al., 2000); or increased in patients with schizophrenia (Hinsberger et al., 
Table 1. Composition of pipette solutions used in this study

\begin{tabular}{lllllllll}
\hline Solution & $\begin{array}{l}\text { Free } \\
{\left[\mathrm{Mg}^{2+}\right](\mathrm{mm})}\end{array}$ & $\begin{array}{l}\mathrm{MgCl}_{2} \\
(\mathrm{~mm})\end{array}$ & $\begin{array}{l}\text { Free } \\
{\left[\mathrm{Ca}^{2+}\right](\mathrm{nm})}\end{array}$ & $\begin{array}{l}\mathrm{CaCl}_{2} \\
(\mathrm{~mm})\end{array}$ & $\begin{array}{l}\text { EGTA } \\
(\mathrm{mm})\end{array}$ & $\begin{array}{l}\text { EDTA } \\
(\mathrm{mm})\end{array}$ & $\begin{array}{l}\text { BAPTA } \\
(\mathrm{mm})\end{array}$ & $\begin{array}{l}\mathrm{KCl} \\
(\mathrm{mm})\end{array}$ \\
\hline I & 0.01 & 0.14 & 25 & 0.89 & 5 & 0.2 & 2 & 121.2 \\
II & 0.1 & 0.13 & 25 & 0.86 & 5 & 0 & 2 & 121 \\
III & 1 & 1.26 & 25 & 0.83 & 5 & 0 & 2 & 119.3 \\
IV & 5 & 6.1 & 25 & 0.72 & 5 & 0 & 2 & 112.2 \\
V & 10 & 12 & 25 & 0.62 & 5 & 0 & 2 & 103.5 \\
VI & 10 & 12 & 0 & 0 & 5 & 0 & 10 & 100.4 \\
\hline
\end{tabular}

Concentrations of free $\mathrm{Mg}^{2+}$ and $\mathrm{Ca}^{2+}$ were calculated using Maxchelator software (see Materials and Methods). In addition to the components indicated, each solution contained (in $\mathrm{mm}$ ) the following: $10 \mathrm{NaAsp}, 5$ tetraethylammonium, 5 HEPES. Differences in osmolarity were compensated for with different concentrations of $\mathrm{KCl}$, and solutions were titrated to $\mathrm{pH} 7.2$ with $\mathrm{KOH}$.

1997). Together these findings suggest that changes in neuronal $\left[\mathrm{Mg}^{2+}\right]_{\mathrm{i}}$ during physiological as well as pathological conditions can be sufficient to modulate electrical synapses.

Here we show that Cx36 GJs are inhibited by resting $\left[\mathrm{Mg}^{2+}\right]_{\mathrm{i}}$ $(\sim 1 \mathrm{~mm})$ and that $g_{\mathrm{j}}$ can be augmented or reduced by lowering or increasing $\left[\mathrm{Mg}^{2+}\right]_{\mathrm{i}}$, respectively. We find that intracellular ATP is critical for the $\mathrm{Mg}^{2+}$-dependent modulation of Cx36 GJs and propose that $\mathrm{Mg}^{2+}$ is directly involved in channel gating by interacting with a sensorial domain located in the channel lumen. Our results indicate that $\mathrm{Mg}^{2+}$ occupancy of Cx36 GJ channels induces a reduction in open probability by increasing sensitivity to $V_{\mathrm{j}}$-induced closure of fast gates, and stabilization of a closed conformation of slow gates. Finally, we show that Cx36containing electrical synapses between $\mathrm{MesV}$ neurons respond similarly to changes in $\left[\mathrm{Mg}^{2+}\right]_{\mathrm{i}}$, indicating that this novel $\mathrm{Mg}^{2+}$ dependent modulatory mechanism of Cx36 GJs is relevant for the modification of neuronal electrical transmission.

\section{Materials and Methods}

Cell lines and culture conditions. Experiments were performed in HeLa (human cervical carcinoma cells, ATCC CCL2) or N2A (mouse neuroblastoma cells, CCL-131) cells transfected with Cx26, Cx32, Cx36, Cx43, $\mathrm{Cx} 45$, or $\mathrm{Cx} 47$ wild type or fused with color variants of green fluorescent proteins (EGFP or CFP) attached to the $\mathrm{C}$ terminus. We also used Novikoff cells expressing endogenous $\mathrm{Cx} 43$. Cells were grown in DMEM supplemented with $8 \%$ fetal calf serum, $100 \mu \mathrm{g} / \mathrm{ml}$ streptomycin, and $100 \mathrm{U} / \mathrm{ml}$ penicillin, and maintained at $37^{\circ} \mathrm{C}$ in humidified air with $5 \%$ $\mathrm{CO}_{2}$. Vectors for transfection and cell lines stably expressing the Cxs used were developed in collaboration with the laboratories of Dr. K. Willecke (Cx36 and Cx47) and Dr. D.W. Laird (Cx43). More details on these issues were published previously (Bukauskas et al., 2000; Teubner et al., 2000, 2001). Phosphomimetic mutants of Cx36 were introduced into wild-type Cx36 (Al-Ubaidi et al., 2000) at Ser110 and Ser293 using the QuikChange Multi Site-directed mutagenesis kit (Agilent). Mutants were subcloned into pEGFP-N1 (Clontech) and transfected into HeLa cells using Lipofectamine 2000 (Invitrogen).

In vitro electrophysiological measurements. Experiments were performed in a modified Krebs'-Ringer's solution containing the following (in mM): $140 \mathrm{NaCl}, 4 \mathrm{KCl}, 2 \mathrm{CaCl}_{2}, 1 \mathrm{MgCl}_{2}, 2 \mathrm{CsCl}, 1 \mathrm{BaCl}_{2}, 5$ glucose, 2 pyruvate, 5 HEPES, pH 7.4. Recording pipettes (3-5 M $\Omega$ ) were filled with standard pipette solution containing the following (in $\mathrm{mM}$ ): 140 $\mathrm{KCl}, 10 \mathrm{NaAsp}, 1 \mathrm{MgCl}_{2}, 0.26 \mathrm{CaCl}_{2}, 2$ EGTA, 5 HEPES, pH 7.2. To study the effect of $\left[\mathrm{Mg}^{2+}\right]_{\mathrm{i}}$, from 0.01 to $10 \mathrm{mM}$, we used pipette solutions containing different concentrations of $\mathrm{MgCl}_{2}$ (Table 1) and applied the web-based Maxchelator software to calculate free ionic concentrations (www.stanford.edu/ $\sim$ cpatton/webmaxcS.htm). To study the effect of divalents other than $\mathrm{Mg}^{2+}$, we used pipette solutions containing the following (in mM): $140 \mathrm{KCl}, 10 \mathrm{NaAsp}, 5 \mathrm{HEPES}, \mathrm{pH} 7.2$, with or without $2 \mathrm{~mm} \mathrm{XCl}_{2}$ of $\mathrm{X}$ divalent. For simultaneous electrophysiological and fluorescence recordings, cells were grown on glass coverslips and transferred to an experimental chamber mounted on the stage of an inverted microscope (Olympus IX70) equipped with a fluorescence imaging sys- tem. Cells were perfused with modified Krebs'-Ringer's solution at room temperature. Junctional conductance $\left(g_{\mathfrak{j}}\right)$ was measured using a dual whole-cell voltage-clamp system. Briefly, each cell of a pair was voltageclamped independently with a separate patch-clamp amplifier (EPC-8, HEKA). By stepping the voltage in cell- $1\left(V_{1}\right)$ and keeping the voltage in cell-2 $\left(V_{2}\right)$ constant, we generated a transjunctional voltage $\left(V_{\mathrm{j}}=\Delta V_{1}\right)$, and the corresponding junctional current $\left(I_{\mathrm{j}}\right)$ was measured as the negative of the current change in cell- $2, I_{\mathrm{j}}=-\Delta I_{2} ; I_{\mathrm{j}}$ has the same polarity as the voltage step in cell- 1 . Thus, $g_{j}$ was obtained from the equation $g_{j}=$ $I_{\mathrm{j}} / V_{\mathrm{j}}$. Signals were acquired and analyzed using custom-made software (Trexler et al., 1999) and an analog-to-digital converter from Molecular Devices.

Brain-slice preparation and ex vivo electrophysiological measurements. A minimum number of animals were killed in accordance with the $\mathrm{Na}$ tional Institutes of Health Guide for the Care and Use of Laboratory Animals, and according to the Institutional Animal Care and Use Committee of Albert Einstein College of Medicine. Transverse brainstem slices (250 $\mu \mathrm{m}$ thick) were prepared from male or female Sprague Dawley rats (age, postnatal day $14-18$ ). Slices were obtained using a vibratome (DTK Microslicer) and placed in cold sucrose solution containing the following (in mM): 248 sucrose, $2.69 \mathrm{KCl}, 1.25 \mathrm{KH}_{2} \mathrm{PO}_{4}, 26 \mathrm{NaHCO}_{3}, 10$ glucose, 2 $\mathrm{CaCl}_{2}$, and $2 \mathrm{MgSO}_{4}$. The slices were then transferred to an incubation chamber filled with sucrose solution at room temperature and incubated for $60 \mathrm{~min}$. The sucrose solution was slowly replaced by physiological solution containing (in mM); $124 \mathrm{NaCl}, 2.69 \mathrm{KCl}, 1.25 \mathrm{KH}_{2} \mathrm{PO}_{4}, 26$ $\mathrm{NaHCO}_{3}, 10$ glucose, $2 \mathrm{CaCl}_{2}$, and $2 \mathrm{MgSO}_{4}$. Sections were kept at room temperature in the physiological solution until they were transferred into the recording chamber. The recording chamber, mounted on an upright microscope stage (Nikon Eclipse E600), was continuously perfused with physiological solution (1-1.5 $\mathrm{ml} / \mathrm{min}$ ) at room temperature. Whole-cell patch recordings were performed under visual control using infrared differential interference contrast optics (IR-DIC). MesV neurons were identified on the basis of their location, large spherical somata, and characteristic electrophysiological properties in response to both depolarizing and hyperpolarizing current pulses (Curti et al., 2012). Recording pipettes $(6-12 \mathrm{M} \Omega$ ) were filled with intracellular solution containing the following (in mM): $140 \mathrm{~K}$-gluconate, $3 \mathrm{MgCl}_{2}, 0.2 \mathrm{EGTA}, 10 \mathrm{HEPES}, \mathrm{pH}$ 7.2. Free $\mathrm{Mg}^{2+}$ was adjusted to $0.01 \mathrm{~mm}$ by adding $4 \mathrm{~mm}$ EDTA, or to 5 mu by adding $2 \mathrm{~mm} \mathrm{MgCl}_{2}$. Simultaneous recordings were made using a Multiclamp 700B amplifier (Molecular Devices), acquired and analyzed using Igor software (Wave Metrics).

Estimates of the junctional conductance between MesV neurons $\left(G_{j}\right)$ were calculated following Bennett, 1966 and Parker et al., 2009:

$$
G_{j}=\frac{R_{\text {transfer }}}{\left(R_{\text {input } 1} \times R_{\text {input } 2}\right)-\left(R_{\text {transfer }}\right)^{2}}
$$

where $R_{\text {input } 1}$ and $R_{\text {input2 } 2}$ represent the input resistance of cell-1 and cell-2, respectively, and $R_{\text {transfer }}$ represents the transfer resistance between coupled cells. The $R_{\text {transfer }}$ is defined as the amplitude of the voltage response measured in cell-1 or cell-2, divided by the amplitude of the current step injected into cell- 2 or cell-1, respectively. To calculate $G_{\mathrm{j}}$ in current-clamp configuration, hyperpolarizing current pulses $(-300 \mathrm{pA})$ of 200-400 ms duration were injected into one cell and the resulting voltage deflections were measured in both cells. A total of 5-20 single responses were averaged to improve the signal-to-noise ratio, and for each coupled pair the mean $G_{j}$ was calculated as the average from the values in both directions. In a linear system, $R_{\text {transfer }}$ is equal in both directions. These estimates assume a simple two-neuron model with passive membrane properties coupled directly by a single domain isopotential on each side. Voltage dependence of $G_{\mathrm{j}}$ is assumed to be negligible, and additional pathways via coupled dendrites or adjacent coupled neurons are excluded. These assumptions are reasonable for Cx36 GJs (Srinivas et al., 1999; Teubner et al., 2000; Moreno et al., 2005) and anatomy of MesV neurons (Curti et al., 2012).

Fluorescence imaging and magnesium transfer studies. Fluorescence signals were acquired using an ORCA digital camera (Hamamatsu) with UltraVIEW software for image acquisition and analysis (PerkinElmer Life Sciences). For magnesium transfer studies, the tetrapotassium salt of 

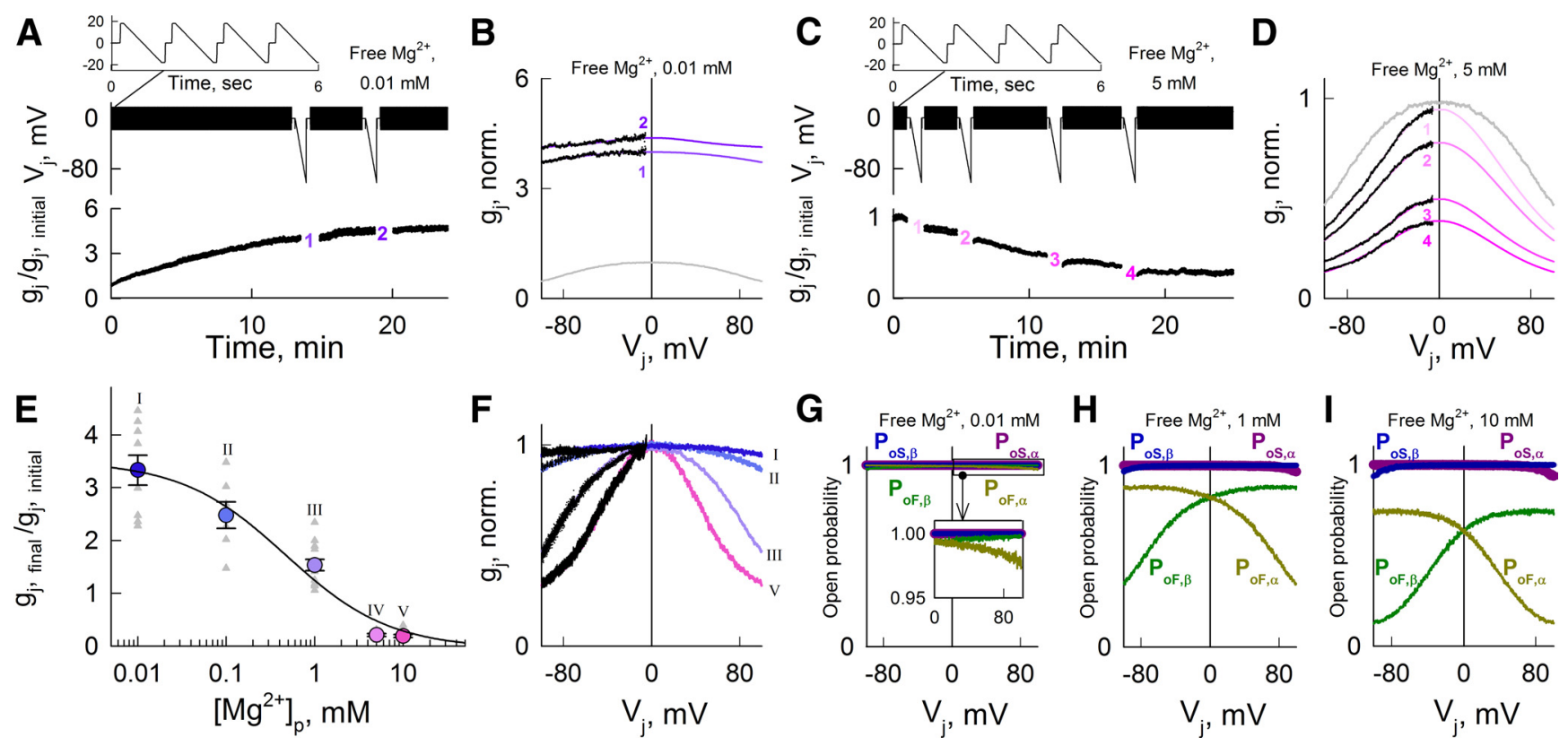

Figure 1. $\mathrm{Mg}^{2+}$-dependent modulation of $g_{\mathrm{j}}$ and $V_{\mathrm{j}}$-gating in HeLa cells expressing (x36-EGFP GJs. $A, C$, Bottom, Dynamics of $g_{\mathrm{j}}$ (normalized to initial $g_{\mathrm{j}}$ value) during repeated $V_{\mathrm{j}}$ ramps $\left(+20--20 \mathrm{mV}\right.$ and $1.3 \mathrm{~s}$ in duration; top traces) at $\left[\mathrm{Mg}^{2+}\right]_{\mathrm{p}}=0.01(\boldsymbol{A})$ and $5 \mathrm{~mm}(\boldsymbol{C}) \cdot \boldsymbol{B}, \boldsymbol{D}, g_{\mathrm{j}}-V_{\mathrm{j}}$ dependence (normalized to initial $g_{\mathrm{j}}$ value at $V_{\mathrm{j}}=0$ ) obtained during 50 -s-long $V_{\mathrm{j}}$ ramps (from 0 to $-100 \mathrm{mV}$; middle traces) derived from data shown in $\boldsymbol{A}$ and $C$, respectively; the numbers on the $g_{\mathrm{j}}-V_{\mathrm{j}}$ plots correspond to numbers on $g_{\mathrm{j}} \operatorname{traces}$ in $\boldsymbol{A}$ and $\boldsymbol{C}$. Fitted curves shown in color were obtained using the S16SM. Gray lines show fitted curves obtained from control $g_{\mathrm{j}}-V_{\mathrm{j}}$ plots $\left(\left[\mathrm{Mg}^{2+}\right]_{\mathrm{p}}=1 \mathrm{mM}\right)$. $E$, Concentration-response relation of $g_{\mathrm{j}}$ (normalized to initial $g_{\mathrm{j}}$ value) as a function of $\left[\mathrm{Mg}^{2+}\right]_{\mathrm{p}} ; \mathrm{EC}_{50} \approx 0.45 \mathrm{~mm}$. Averaged data are shown in colored circles. Data of individual experiments are shown in gray triangles. Roman numerals correspond to different solutions shown in Table 1. $\boldsymbol{F}$, Averaged $g_{\mathrm{j}}-V_{\mathrm{j}}$ dependencies (normalized to $g_{\mathrm{j}}$ value at $V_{\mathrm{j}}=0$ ) obtained at different $\left[\mathrm{Mg}^{2+}\right]_{\mathrm{p}}$ (curves in black) were fitted using a S16SM ( $g_{\mathrm{j}}-V_{\mathrm{j}}$ plots in colors). Roman numerals correspond to different $\mathrm{Mg}^{2+}$ concentrations shown in $\boldsymbol{E}$. Parameters obtained after fitting are shown in Table 2. G-I, Open probabilities of fast and slow gates in $\alpha$ and $\beta$ aHCs $\left(P_{0 F}, \alpha^{\prime} P_{0 S, \alpha}\right.$ and $P_{\mathrm{oF}, \beta^{\prime}} P_{\mathrm{oS}, \beta^{\prime}}$ respectively) depending on $V_{\mathrm{j}}$ were calculated using parameters obtained in $\boldsymbol{F}$ for $\left[\mathrm{Mg}^{2+}\right]_{\mathrm{p}}=0.01(\boldsymbol{G}), 1(\boldsymbol{H})$, and $10 \mathrm{~mm}(\boldsymbol{I})$.

the magnesium fluorescent probe $(50 \mu \mathrm{M})$, Mag-Fluo-4 (Invitrogen), was introduced into cell-1 of a pair through a patch pipette with modified standard pipette solution without $\mathrm{MgCl}_{2}$. Pipette solution for cell-2 was modified with addition of $9 \mathrm{~mm} \mathrm{MgCl}_{2}$. Typically, breaking into cell-1 was followed by an increased fluorescence intensity in cell-1 $\left(\mathrm{FI}_{1}\right)$. After reaching steady state in cell-1, the patch in cell-2 was opened and the changes in $\mathrm{FI}_{1}$ and $g_{\mathrm{j}}$ were measured. The rate of $\mathrm{FI}_{1}$ changes [ (arbitrary units per minute $(\mathrm{AU} / \mathrm{min})$ ] was calculated as the difference between $\mathrm{FI}_{1}$ at the moment of breaking into cell-2 and $\mathrm{FI}_{1}$ after 2 min.

Data analysis. The analysis and statistics were performed using SigmaPlot software. Averaged data are reported as the means \pm SEM. Means for each group were compared using unpaired Student's $t$ test.

\section{Results}

Intracellular magnesium-dependent modulation of junctional conductance and voltage-gating of $\mathrm{Cx} 36$ GJ channels

To understand the influence of $\mathrm{Mg}^{2+}$ on Cx36-mediated electrical coupling, we studied changes in $g_{\mathrm{j}}$ and $g_{\mathrm{j}}-V_{\mathrm{j}}$ dependence at different $\left[\mathrm{Mg}^{2+}\right]_{\mathrm{i}}$ in pairs of HeLa cells expressing Cx36 wild type, and HeLa or N2A cells expressing Cx36 tagged with EGFP (Cx36-EGFP) using dual whole-cell patch clamp. We changed $\left[\mathrm{Mg}^{2+}\right]_{\mathrm{i}}$ using pipette solutions containing from 0.01 to $10 \mathrm{mM}$ free $\mathrm{Mg}^{2+}\left(\left[\mathrm{Mg}^{2+}\right]_{\mathrm{p}}\right)$ with compositions (Table 1) determined using the Maxchelator program (see Materials and Methods). The pipette solutions also contained $5 \mathrm{~mm}$ EGTA and $2 \mathrm{~mm}$ BAPTA to buffer free $\mathrm{Ca}^{2+}$ concentration at $25 \mathrm{nM}$. Basal $g_{\mathrm{j}}$ was measured with small-amplitude $V_{\mathrm{j}}$ ramps (+20--20 mV; duration, $1.3 \mathrm{~s}$ ), and $g_{j}-V_{\mathrm{j}}$ dependence was measured with highamplitude $V_{\mathrm{j}}$ ramps (from 0 to $-100 \mathrm{mV}$; duration, $50 \mathrm{~s}$ ). When both pipettes contained $\left[\mathrm{Mg}^{2+}\right]_{\mathrm{p}}=0.01 \mathrm{~mm}, g_{\mathrm{j}}$ of Cx36 GJs increased after patch opening (Fig. $1 A$ ), and became less $V_{\mathrm{j}^{-}}$ sensitive than in control condition with $\left[\mathrm{Mg}^{2+}\right]_{\mathrm{p}}=1 \mathrm{~mm}$ (Fig.
1B). In contrast, $\left[\mathrm{Mg}^{2+}\right]_{\mathrm{p}}=5 \mathrm{~mm}$ in both pipettes led to a reduction in $g_{\mathrm{j}}$ (Fig. 1C) and increased $V_{\mathrm{j}}$-sensitivity compared with control (Fig. $1 D$ ). In both cases, the $g_{\mathrm{j}}$ reached steady state within $\sim 20$ min. A steady-state $g_{\mathrm{j}}-\left[\mathrm{Mg}^{2+}\right]_{\mathrm{p}}$ curve normalized to initial $g_{\mathrm{j}}$ values (Fig. $1 E$ ) shows a half maximal effective concentration $\left(\mathrm{EC}_{50}\right)$ of $0.45 \mathrm{mM}$. All $g_{\mathrm{j}}-V_{\mathrm{j}}$ relations shown in Figure $1 B, D$ were fitted using a stochastic 16-state model (S16SM) of voltage gating (Paulauskas et al., 2012) containing in series for each aHC two $V_{\mathrm{j}}$-sensitive gates, a fast gate and a slow gate (Bukauskas and Weingart, 1994).

In the S16SM, fast gates have an open state with conductance $\gamma_{\mathrm{F}, \text { open }}$ and a "closed" or residual state with conductance $\gamma_{\mathrm{F}, \mathrm{res}}>$ 0 . Meanwhile, slow gates have an open state with conductance $\gamma_{\mathrm{S} \text {,open }}$ and a closed state with zero conductance $\left(\gamma_{\mathrm{S} \text {,closed }}=0\right)$. Therefore, the channel can occupy one of the 16 possible states made by the combination of four states of the fast gates with four states of the slow gates. For simplicity we assume that $\gamma_{\mathrm{F}, \text { open }}=$ $\gamma_{\mathrm{S} \text {,open }}$, and that conductance of the fully open channel $\gamma_{\text {open }}=$ $\gamma_{\mathrm{F}, \text { open }} / 4=\gamma_{\mathrm{S} \text {,open }} / 4$. The behavior of each gate is characterized by Boltzmann equilibrium constants between open and residual/ closed states, for fast $\left(K_{\mathrm{F}, \mathrm{o} \leftrightarrows \mathrm{res}}=e^{A_{\mathrm{F}}\left(-\Pi \cdot V_{\mathrm{F}}-V_{\mathrm{F}, 0}\right)}\right)$ or slow $\left(K_{\mathrm{S}, \mathrm{o} \leftrightarrows \mathrm{c}}=\right.$ $\left.e^{A_{\mathrm{S}}\left(-\Pi \cdot V_{\mathrm{S}}-V_{\mathrm{S}, 0}\right)}\right)$ gates, where $A\left(A_{\mathrm{F}}\right.$ and $\left.A_{\mathrm{S}}\right)$ characterize the maximal steepness of changes in open probability $\left(P_{\mathrm{oF}}\right.$ and $\left.P_{\mathrm{oS}}\right)$ as a function of voltage across the gate $\left(V_{\mathrm{F}}\right.$ and $\left.V_{\mathrm{S}}\right), V_{\mathrm{o}}\left(V_{\mathrm{F}, \mathrm{o}}\right.$ and $\left.V_{\mathrm{S}, \mathrm{o}}\right)$ is the voltage across the gate at which its probability to be in the open state is 0.5 , and $\Pi$ is a gating polarity $(+1$ or -1$)$. Thus, the S16SM allowed us to estimate gating parameters characterizing sensitivity to $V_{\mathrm{j}}$ for each gate and the number of operational/ functional channels $\left(N_{\mathrm{F}}\right)$. In addition, the S16SM uses an exponential function to describe rectification over voltage (e.g., $\gamma_{\mathrm{F}, \text { res }}=$ $\gamma_{\mathrm{F}, \text { res }, 0} e^{-V_{\mathrm{F}} / R_{\mathrm{F}}}$, where $\gamma_{\mathrm{F}, \text { res }, 0}$ is $\gamma_{\mathrm{F} \text {,res }}$ at $V_{\mathrm{F}}=0$ ), therefore allowing 
Table 2. Parameters of voltage-gating estimated with S16SM

\begin{tabular}{|c|c|c|c|c|c|c|c|c|c|}
\hline \multirow[b]{2}{*}{ Figure $(C x)$} & \multicolumn{5}{|l|}{ Fast gate } & \multicolumn{4}{|l|}{ Slow gate } \\
\hline & $A_{\mathrm{F}}\left(\mathrm{mV}^{-1}\right)$ & $V_{\mathrm{F}, 0}(\mathrm{mV})$ & $\gamma_{\mathrm{F}, \text { open }}(\mathrm{pS})$ & $\gamma_{F, \text { res }}(p S)$ & $R_{\mathrm{F}, \mathrm{res}}(\mathrm{mV})$ & $A_{S}\left(\mathrm{mV}^{-1}\right)$ & $V_{s, 0}(m V)$ & $\gamma_{\mathrm{S}, \text { open }}(\mathrm{pS})$ & $\gamma_{\mathrm{S}, \text { losed }}(\mathrm{pS})$ \\
\hline \multicolumn{10}{|l|}{$1 F(C \times 36)$} \\
\hline Solution I & 0.041 & 122 & 24 & 0.6 & & 0.100 & 154 & 24 & 0 \\
\hline Solution III & 0.037 & 41 & 24 & 0.5 & & 0.085 & 77 & 24 & 0 \\
\hline Solution V & 0.045 & 12 & 24 & 0.6 & & 0.084 & 68 & 24 & 0 \\
\hline \multicolumn{10}{|l|}{$3 H(C \times 47)$} \\
\hline Solution IV & 0.14 & 27 & 220 & 6.2 & 272 & 0.09 & 103 & 220 & 0 \\
\hline Solution V & 0.16 & 21 & 220 & 6.2 & 210 & 0.11 & 86 & 220 & 0 \\
\hline
\end{tabular}

Parameters were obtained from the fitting of $g_{\mathrm{j}}-V_{\mathrm{j}}$ data shown in Figures $1 F$ and $3 \mathrm{H}$ using the stochastic 16 -state model of $\mathrm{GJ}$ channels (S16SM).

an estimate of rectification coefficients for the conductive states of fast $\left(R_{\mathrm{F}, \text { open }}\right.$ and $\left.R_{\mathrm{F}, \text { res }}\right)$ and slow $\left(R_{\mathrm{S} \text {,open }}\right)$ gates. $V_{\mathrm{j}}$ across the GJ channel is the sum of voltages across all gates, $V_{\mathrm{j}}=V_{\mathrm{F}, \alpha}+V_{\mathrm{S}, \alpha}+V_{\mathrm{F}, \beta}+$ $V_{\mathrm{S}, \beta}$, where $\alpha$ and $\beta$ stand for the two aHCs. Closing one gate changes the voltage across the other three gates in series, and this affects the probability of the state's changing over a discreet time interval. The residual conductance of the GJ channel $\left(\gamma_{\text {res }}\right)$ typically is approximately one-fifth of $\gamma_{\text {open }}$ (Bukauskas and Verselis, 2004), which is measured when one of fast gates is in the closed/residual state and three other gates in series are in the open state $\left(1 / \gamma_{\text {res }}=1 / \gamma_{\mathrm{F}, \text { res }}+1 / \gamma_{\mathrm{F}, \text { open }}+\right.$ $\left.2 / \gamma_{\mathrm{S} \text {,open }}\right)$. Values of $A$ and $V_{\mathrm{o}}$ for fast and slow gates estimated during the fitting process allowed calculation of open probabilities for each gate in $\alpha$ and $\beta$ aHCs $\left(P_{\mathrm{oF}, \alpha}, P_{\mathrm{oS}, \alpha}, P_{\mathrm{oF}, \beta}\right.$, and $\left.P_{\mathrm{oS}, \beta}\right)$ and the probability of a GJ channel to reside in a fully open state $\left(P_{\mathrm{o}} ; 4\right.$ gates in the open state) as a function of $V_{\mathrm{j}}$. Fitting of averaged experimental $g_{\mathrm{j}}-V_{\mathrm{j}}$ dependence normalized to $g_{\mathrm{j}}$ values at $V_{\mathrm{j}}=0$ (Fig. $1 F$, black lines; we assumed symmetry of the $g_{\mathrm{j}}-V_{\mathrm{j}}$ relation around $V_{\mathrm{j}}=0$; fitted curves are in colors) revealed that with reduction of $\left[\mathrm{Mg}^{2+}\right]_{\mathrm{p}}$, $V_{\mathrm{F}, \mathrm{o}}$ and $V_{\mathrm{S}, \mathrm{o}}$ increased while $A_{\mathrm{F}}$ and $A_{\mathrm{S}}$ remained relatively constant (Table 2 ). $V_{\mathrm{o}}$ and $A$ for both fast and slow gates, and $\gamma_{\mathrm{F}, \text { res }}$ were set as free parameters during the fitting process (Table 2). Figure $1 G-I$ shows open probability of each gate as functions of $V_{\mathrm{j}}$ derived from $g_{\mathrm{j}}-V_{\mathrm{j}}$ plots obtained at different $\left[\mathrm{Mg}^{2+}\right]_{\mathrm{p}}$ and shown in Figure $1 F$. At $\left[\mathrm{Mg}^{2+}\right]_{\mathrm{p}}=$ $0.01 \mathrm{~mm}$ (Fig. $1 G)$, all gates remain open ( $P_{\mathrm{o}}$ close to unity) over the entire $V_{\mathrm{j}}$ range. At $\left[\mathrm{Mg}^{2+}\right]_{\mathrm{p}}=1 \mathrm{mM}($ Fig. $1 H), P_{\mathrm{oF}, \alpha}$ and $P_{\mathrm{oF}, \beta}$ showed enhanced sensitivity to $V_{\mathrm{j}}$ with a value of 0.8 at $V_{\mathrm{j}}=0$, and $P_{\mathrm{oS}, \alpha}$ and $P_{\mathrm{oS}, \beta}$ remain close to unity at $V_{\mathrm{j}}=0$. Therefore, on average, only $64 \%$ of functional GJ channels have all four gates in the open state at $\left[\mathrm{Mg}^{2+}\right]_{\mathrm{p}}=1 \mathrm{~mm}$ and $V_{\mathrm{j}}=0$. At $\left[\mathrm{Mg}^{2+}\right]_{\mathrm{p}}=10 \mathrm{~mm}$ (Fig. $1 I$ ), $P_{\mathrm{oF}, \alpha}$ and $P_{\mathrm{oF}, \beta}$ show even higher sensitivity to $V_{\mathrm{j}}$ corresponding to the shift of $P_{\mathrm{oF}, \alpha}$ and $P_{\mathrm{oF}, \beta}$ plots along the $V_{\mathrm{j}}$ axis, but $P_{\mathrm{oS}, \alpha}$ and $P_{\mathrm{oS}, \beta}$ did not change very much. As a result, $P_{\mathrm{o}}$ at $V_{\mathrm{j}}=0$ was reduced to $\sim 0.36$. Thus, $P_{\mathrm{o}}$ at $\left[\mathrm{Mg}^{2+}\right]_{\mathrm{i}}=10 \mathrm{mM}$ was $\sim 2.8$-fold less than $P_{\mathrm{o}}$ at $0.01 \mathrm{mM}$, and changes in $P_{\mathrm{oF}, \alpha}$ and $P_{\mathrm{oF}, \beta}$ caused by changes in $V_{\mathrm{o}} \mathrm{s}$ account for $\sim 80 \%$ of the changes in $g_{\mathrm{j}}$ as a function of $\left[\mathrm{Mg}^{2+}\right]_{\mathrm{i}}$.
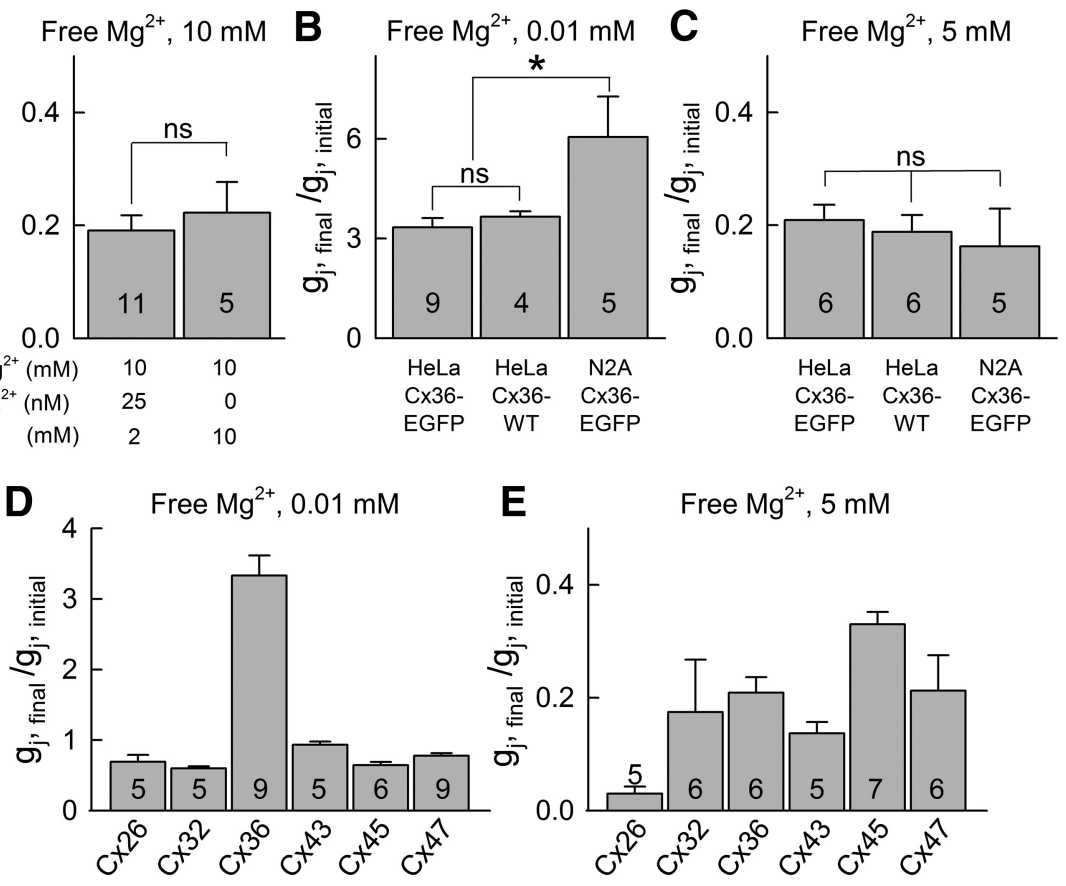

Figure 2. Differences in $\left[\mathrm{Mg}^{2+}\right]_{\mathrm{i}}$-dependent modulation of $g_{\mathrm{j}}$ in HeLa or N2A cells expressing $\mathrm{Cx} 26, \mathrm{Cx} 32, \mathrm{Cx} 36, \mathrm{Cx} 43, \mathrm{C} \times 45$, or $\mathrm{Cx} 47$; changes in $\left[\mathrm{Ca}^{2+}\right]_{i}$ are not involved in $\left[\mathrm{Mg}^{2+}\right]_{i}$-dependent modulation of $C \times 36$. All data represent mean $g_{j}$ (normalized to $2 \mathrm{~mm}$ BAPTA (free $\mathrm{Ca}^{2+}=25 \mathrm{~nm}$ ) or $10 \mathrm{~mm}$ BAPTA (free $\mathrm{Ca}^{2+} \approx 0$ ). $\boldsymbol{B}, \boldsymbol{C}$, Normalized $g_{\mathrm{j}}$ measured using pipette solutions containing $0.01(\boldsymbol{B})$ or $5 \mathrm{~mm}$ free $\mathrm{Mg}^{2+}(\boldsymbol{C})$ in HeLa (x36WT, HeLa Cx36-EGFP, or N2A Cx36-EGFP cell pairs. D, E, Normalized $g$ measured using pipette solutions containing 0.01 (D) or $5 \mathrm{~mm}(\boldsymbol{E})$ of free $\mathrm{Mg}^{2+}$ in HeLa cells expressing $\mathrm{C} \times 26, \mathrm{C} \times 32, \mathrm{C} \times 36, \mathrm{C} \times 43$, $\mathrm{C} \times 45$, or $\mathrm{Cx} 47$. Numbers of cell pairs are indicated within columns; ${ }^{*} p<0.05$; ns, nonsignificant $p$ values.

The remaining $\sim 20 \%$ can be explained by changes in $N_{\mathrm{F}}$, where channels may enter into a $\mathrm{Mg}^{2+}$-occupied (long-lived) closed conformation of the slow gate.

To test whether the decrease in coupling under high $\left[\mathrm{Mg}^{2+}\right]_{\mathrm{i}}$ depends on changes in intracellular free $\mathrm{Ca}^{2+}$ concentration $\left(\left[\mathrm{Ca}^{2+}\right]_{\mathrm{i}}\right)$, we enhanced the buffering capacity of the pipette solution by increasing BAPTA to $10 \mathrm{~mm}$ (Table 1, Solution VI), which reduced $\left[\mathrm{Ca}^{2+}\right]_{\mathrm{p}}$ close to zero. We did not find significant differences in $g_{\mathrm{j}}$ decay under high $\left[\mathrm{Mg}^{2+}\right]_{\mathrm{i}}$ conditions $(10 \mathrm{mM})$ with normal/ control $(25 \mathrm{nM})$ or close to zero $\left[\mathrm{Ca}^{2+}\right]_{\mathrm{p}}$ (Fig. $\left.2 A\right)$. HeLa cells expressing Cx36 and Cx36-EGFP exhibited similar $\mathrm{Mg}^{2+}$-dependent modulation of $g_{j}$ (Fig. $2 B, C$ ). However, neuroblastoma cells expressing Cx36-EGFP (N2A-Cx36-EGFP) showed higher increase in $g_{\mathrm{j}}$ than HeLa cells expressing Cx36-EGFP when exposed to $0.01 \mathrm{~mm}$ $\left[\mathrm{Mg}^{2+}\right]_{\mathrm{p}}$ (Fig. 2B). In summary, Cx36 GJs exhibited a "run-up" or "run-down" in $g_{\mathrm{j}}$ when $\left[\mathrm{Mg}^{2+}\right]_{\mathrm{p}}$ in both pipette solutions was lower 
A

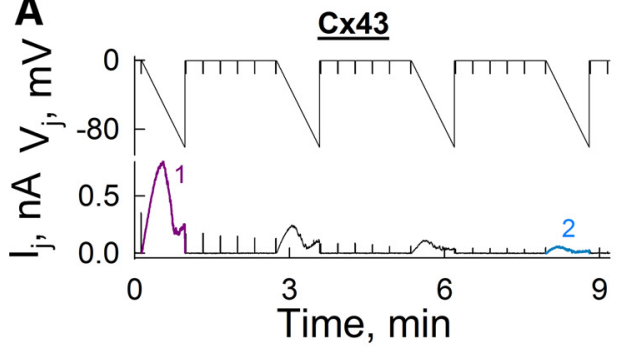

C

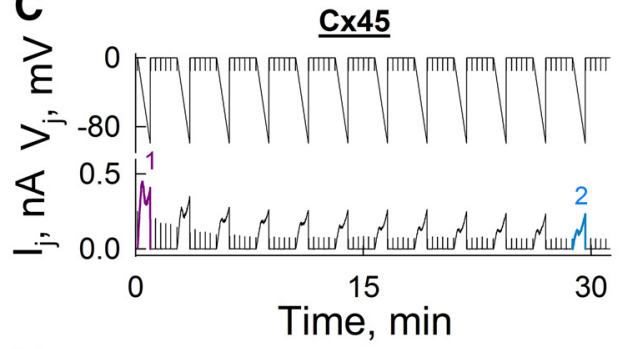

E
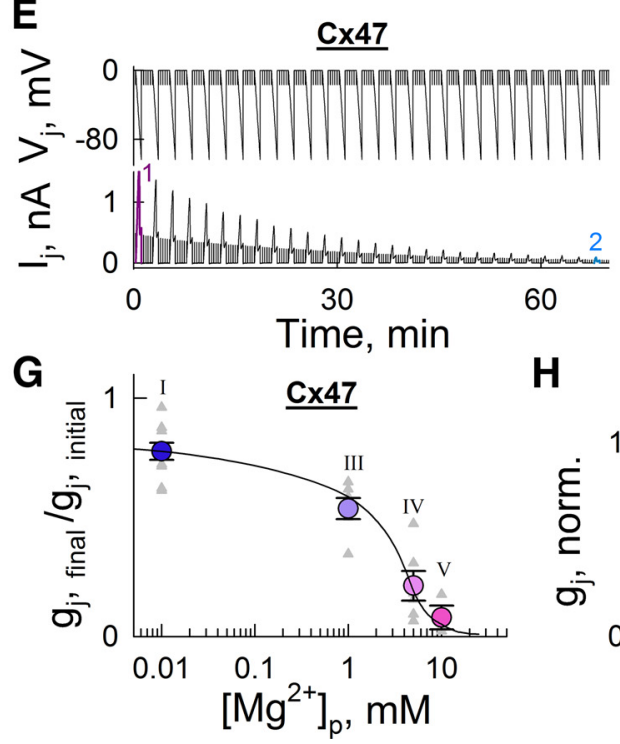

H
B
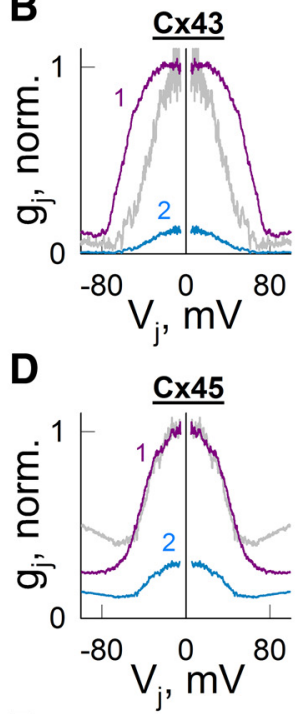

$\mathbf{F}$

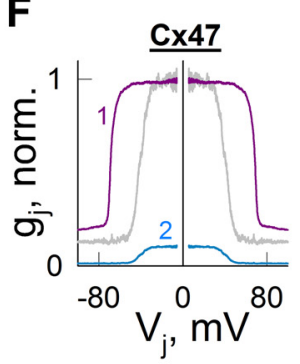

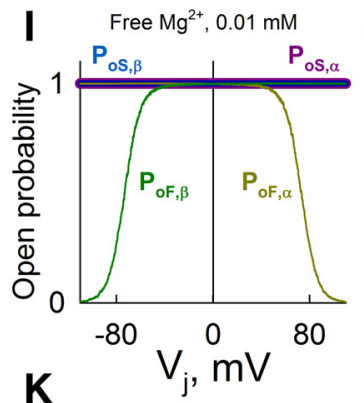

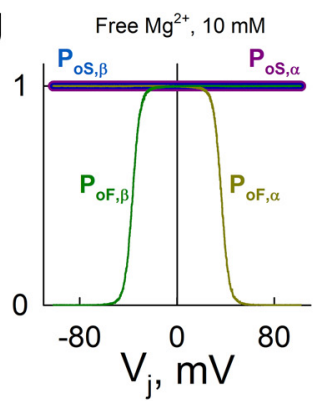

$\underline{\mathrm{Cx} 43}$

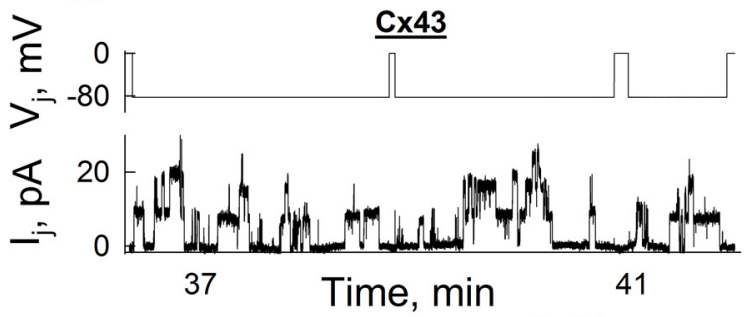

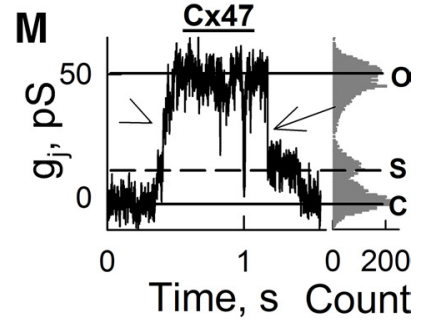
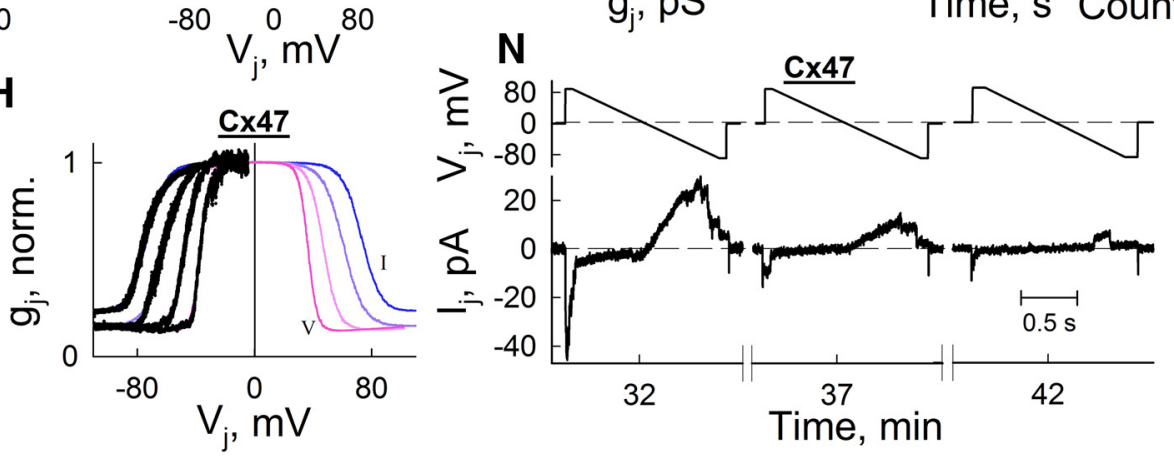

Figure 3. $\left[\mathrm{Mg}^{2+}\right]_{\mathrm{i}}$-dependent modulation of $g_{\mathrm{j}}$ and $V_{\mathrm{j}}$-gating of $\mathrm{GJ}$ s formed by other $\left(x\right.$ s expressed in CNS does not affect single-channel conductance. $A, C, E$, Changes of $l_{\mathrm{j}}$ in response to repeated 50 -s-long $V_{\mathrm{j}}$ ramps from 0 to $-100 \mathrm{mV}$ and intermediate small-amplitude steps $(-15 \mathrm{mV})$ using $\left[\mathrm{Mg}^{2+}\right]_{\mathrm{p}}=5 \mathrm{~mm}$ in Novikoff $(\boldsymbol{A})$, HeLa $(\mathbf{X} 45(\boldsymbol{C})$, and HeLa $(x 47-\mathrm{EGFP}(\boldsymbol{E})$ cell pairs. $\boldsymbol{B}, \boldsymbol{D}, \boldsymbol{F}$, First (purple) and last (cyan) $g_{\mathrm{j}}-V_{\mathrm{j}}$ relations (normalized to initial $g_{\mathrm{j}}$ value at $V_{\mathrm{j}}=0$ ) obtained from experiments shown in $\boldsymbol{A}, \boldsymbol{C}$, and $\boldsymbol{E}$, respectively. Last $g_{\mathrm{j}}-V_{\mathrm{j}}$ relation normalized to $g_{\mathrm{j}}$ value at $V_{\mathrm{j}}=0$ (gray) is also shown for comparison. $G$, Concentration-response relation of $g_{\mathrm{j}}$ (normalized to initial $g_{\mathrm{j}}$ value) as a function of $\left[\mathrm{Mg}^{2+}\right]_{\mathrm{p}}$ for $\mathrm{Cx}_{47}$; $\mathrm{EC}{ }_{50} \approx$ $2.8 \mathrm{~mm}$. Averaged data are shown in colored circles; roman numerals correspond to different pipette solutions shown in Table $1 . \boldsymbol{H}$, Averaged $g_{\mathrm{j}}-V_{\mathrm{j}}$ dependence $\left(\right.$ normalized to $g_{\mathrm{j}}$ at $V_{\mathrm{j}}=$ 0 ) obtained at different $\left[\mathrm{Mg}^{2+}\right]_{\mathrm{p}}$ for $\left(x 47\right.$; roman numerals correspond to different $\left[\mathrm{Mg}^{2+}\right]$ shown in $G$ and Table 1. Experimental $g_{j}-V_{j}$ plots shown in black were fitted using the S16SM; calculated values of gating parameters are shown in Table 2 , and the best-fitting $g_{j}-V_{j}$ plots are shown in colors that correspond to colors of circles in $\mathbf{G}$. $I, J$, 0 pen probabilities of fast and slow gates in $\alpha$ and $\beta$ aHCs $\left(P_{\text {of }, \alpha}, P_{0 S, \alpha}\right.$ and $P_{\text {of }, \beta}, P_{o S, \beta}$, respectively) depending on $V_{j}$ were calculated using parameters obtained in $\boldsymbol{H}$ for $\left[\mathrm{Mg}^{2+}\right]_{\mathrm{p}}=0.01(\boldsymbol{I})$ and $10 \mathrm{~mm}(\boldsymbol{J}) . \boldsymbol{K}, I_{\mathrm{j}}$ record of (X43-CFP GJs obtained at $V_{\mathrm{j}}=-80 \mathrm{mV}$. L, Histogram from data in $\boldsymbol{K}$ shows a series of peaks separated by $\sim 96.5 \pm 8 \mathrm{pS}$. $\boldsymbol{M}$, Single-channel conductance for $(\mathrm{x} 47$-EGFP obtained in response to a $V_{\mathrm{j}}$ step of $-52 \mathrm{mV}$. The histogram shows peaks for the closed state, substate $\left(\gamma_{\mathrm{s}}=11.2 \pm 2.3 \mathrm{pS}\right)$, and open state $\left(\gamma_{0}=49 \pm 5.6 \mathrm{pS}\right)$. The arrowhead indicates a slow transition from the closed state to open state, and the arrow indicates a fast transition from the open state to the substate. $N, I_{\mathrm{j}}$ trace from a HeLa CX47-EGFP cell pair in response to 1.5-s-long $V_{\mathrm{j}}$ ramps from 90 to $-90 \mathrm{mV}$ using $\left[\mathrm{Mg}^{2+}\right]_{\mathrm{p}}=5 \mathrm{~mm}$ after 32,37 , and $42 \mathrm{~min}$ of recording.

or higher than $\sim 1.3 \mathrm{~mm}$, respectively, and we assume that $1.3 \mathrm{~mm}$ is the resting $\left[\mathrm{Mg}^{2+}\right]_{\mathrm{i}}$ in $\mathrm{HeLa}$ cells under our experimental conditions (Fig. 1E). Changes in $\left[\mathrm{Mg}^{2+}\right]_{\mathrm{i}}$ have a marked effect on $V_{\mathrm{F}, \mathrm{o}}$, which affects mainly $P_{\mathrm{o}}$ and, to a small degree, $N_{\mathrm{F}}$.

Junctional conductance of GJ channels formed of $\mathrm{Cx} 26, \mathrm{Cx} 32$, $\mathrm{Cx} 43, \mathrm{Cx} 45$, or $\mathrm{Cx} 47$ is also reduced by increase in intracellular magnesium

To compare $\mathrm{Cx} 36$ to other isoforms with respect to the effects of $\left[\mathrm{Mg}^{2+}\right]_{\mathrm{i}}$, we studied $\mathrm{Mg}^{2+}$-dependent modulation of $g_{\mathrm{j}}$ in HeLa cells expressing the following: $\mathrm{Cx} 43$ ( $\alpha$-group); $\mathrm{Cx} 26$ and $\mathrm{Cx} 32$
( $\beta$-group); and $\mathrm{Cx} 45$ and $\mathrm{Cx} 47$ ( $\gamma$-group). In contrast to $\mathrm{Cx} 36$ $(\delta$-group $),\left[\mathrm{Mg}^{2+}\right]_{\mathrm{p}}=0.01 \mathrm{mM}$ did not increase $g_{\mathrm{j}}$ above initial values in all other tested Cxs (Fig. $2 D$ ). However, $\left[\mathrm{Mg}^{2+}\right]_{\mathrm{p}}=5$ mu reduced $g_{j}$ in all tested Cxs (Fig. $2 E$ ). To compare Cx36 to other Cxs expressed in the CNS with respect to $g_{\mathrm{j}}-V_{\mathrm{j}}$ dependence at different $\left[\mathrm{Mg}^{2+}\right]_{\mathrm{i}}$, we chose $\mathrm{Cx} 43, \mathrm{Cx} 45$, and $\mathrm{Cx} 47$, which are expressed in astrocytes, neurons, and oligodendrocytes, respectively. Similar to the effect on $\mathrm{Cx} 36$, high $\left[\mathrm{Mg}^{2+}\right]_{\mathrm{p}}$ increased sensitivity to $V_{\mathrm{j}}$ in $\mathrm{Cx} 43$ - and Cx47-expressing cells (Figs. $3 A, B$, $4 E, F)$; increased $V_{\mathrm{j}}$-sensitivity was not observed in $\mathrm{Cx} 45$ expressing cells (Fig. $3 C, D$ ). Increase in $\left[\mathrm{Mg}^{2+}\right]_{\mathrm{p}}$ to $10 \mathrm{~mm}$ de- 
creased $g_{\mathrm{j}}$ for $\mathrm{Cx} 47$ (normalized to initial values) to 0.08 (Fig. 3G). Steady-state $g_{\mathrm{j}}-V_{\mathrm{j}}$ relationships (normalized to $g_{\mathrm{j}}$ at $\left.V_{\mathrm{j}}=0\right)$ at different $\left[\mathrm{Mg}^{2+}\right]_{\mathrm{p}}$ for $\mathrm{Cx} 47$ (Fig. $3 \mathrm{H}$, black lines) were fitted using the S16SM (Fig. $3 H$, colored lines); all parameters are shown in Table 2. Elevation in $\left[\mathrm{Mg}^{2+}\right]_{\mathrm{i}}$ moderately increased $A_{\mathrm{F}}$ and the maximal steepness of $g_{\mathrm{j}}$-versus $-V_{\mathrm{j}}$ changes, and markedly decreased $V_{\mathrm{F}, \mathrm{o}}$, as is reflected in narrowing of the (flat topped) bell-shaped $g_{\mathrm{j}}-V_{\mathrm{j}}$ plot (Fig. $3 F, H)$. However, $P_{\mathrm{oF}}$ and $P_{\mathrm{oS}}$ at $V_{\mathrm{j}}=0$ remained constant and close to unity for all $\left[\mathrm{Mg}^{2+}\right]_{\mathrm{p}}$, as reflected in the flat top of the $g_{\mathrm{j}}-V_{\mathrm{j}}$ relation (Fig. $3 I, J$ ). Therefore, all changes in $g_{\mathrm{j}}$ observed at $V_{\mathrm{j}}=0$ under different $\left[\mathrm{Mg}^{2+}\right]_{\mathrm{i}}$ are due to a reduction in $N_{\mathrm{F}}$ and not to changes in parameters of $V_{\mathrm{j}}$-gating. In contrast to $g_{\mathrm{j}}$ of the $\mathrm{Cx} 36 \mathrm{GJ}$, $g_{\mathrm{j}}$ of the Cx26, Cx32, Cx43, Cx45, and Cx47 GJs showed spontaneous "run down" even at $\left[\mathrm{Mg}^{2+}\right]_{\mathrm{p}}=0.01 \mathrm{~mm}$ (Fig. $2 D)$. Therefore all data in the $g_{\mathrm{j}}-\left[\mathrm{Mg}^{2+}\right]_{\mathrm{p}}$ dependence for $\mathrm{Cx} 47$ are below unity (Fig. $3 G)$. This decay in $g_{\mathrm{j}}$ of $\mathrm{Cx} 47$ was prevented by adding $3 \mathrm{~mm} \mathrm{~K}_{2}$ ATP to solutions with low $\left[\mathrm{Mg}^{2+}\right]_{\mathrm{p}}$ (data not shown), indicating that stability of these GJs depends on ATP as observed for GJs formed between cardiomyocytes (Sugiura et al., 1990; Verrecchia et al., 1999).

\section{Single-channel conductance of $\mathrm{Cx} 43$ and Cx47 GJs is not affected by high intracellular magnesium}

Previous studies of Cx36 GJs have shown that $\gamma_{\text {open }}$ is very small compared with those of GJs formed of other Cxs (Srinivas et al., 1999; Teubner et al., 2000; Moreno et al., 2005), making the study of changes in $\gamma_{\text {open }}$ under different $\left[\mathrm{Mg}^{2+}\right]_{\mathrm{i}}$ impracticable. Thus, we tested whether $\gamma_{\text {open }}$ of GJ channels formed by Cxs with relatively high $\gamma_{\text {open }}$ (Cx43 and Cx47) were modified by $5 \mathrm{~mm}$ $\left[\mathrm{Mg}^{2+}\right]_{\mathrm{p}}$ (Table 1, Solution IV). Experiments were performed in HeLa cells expressing Cx43-CFP or Cx47-EGFP. The

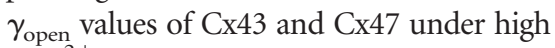
$\left[\mathrm{Mg}^{2+}\right]_{\mathrm{p}}$ did not differ significantly from those previously reported under control conditions (Moreno et al., 1994; Bukauskas et al., 2000; Teubner et al., 2001). We found that, at $\left[\mathrm{Mg}^{2+}\right]_{\mathrm{p}}=5 \mathrm{~mm}, \gamma_{\mathrm{open}}$ of $\mathrm{Cx} 43$ and Cx47 GJ channels was $96.5 \pm 8$ pS (Fig.

$3 K, L$ ), and $49 \pm 5.6 \mathrm{pS}$ (Fig. $3 M$ ), respectively. In the experiment shown in Figure $3 K$, initial $g_{\mathrm{j}}$ at time 0 was $\sim 40 \mathrm{nS}$, corresponding to $\sim 400$ open Cx43 GJ channels. High $\left[\mathrm{Mg}^{2+}\right]_{\mathrm{p}}$ reduced $g_{\mathrm{j}}$ and $\sim 36$ min later no more than three GJ channels were open simultaneously. Similarly, in the experiment shown in Figure $3 N$, initial $g_{\mathrm{j}}$ was $\sim 6 \mathrm{nS}$, corresponding to $\sim 120$ open Cx47 GJ channels. High $\left[\mathrm{Mg}^{2+}\right]_{\mathrm{p}}$ reduced $g_{\text {; }}$, and, after 32, 37, and 42 min, maximum numbers of channels open were seven, three, and one, respectively. In summary,
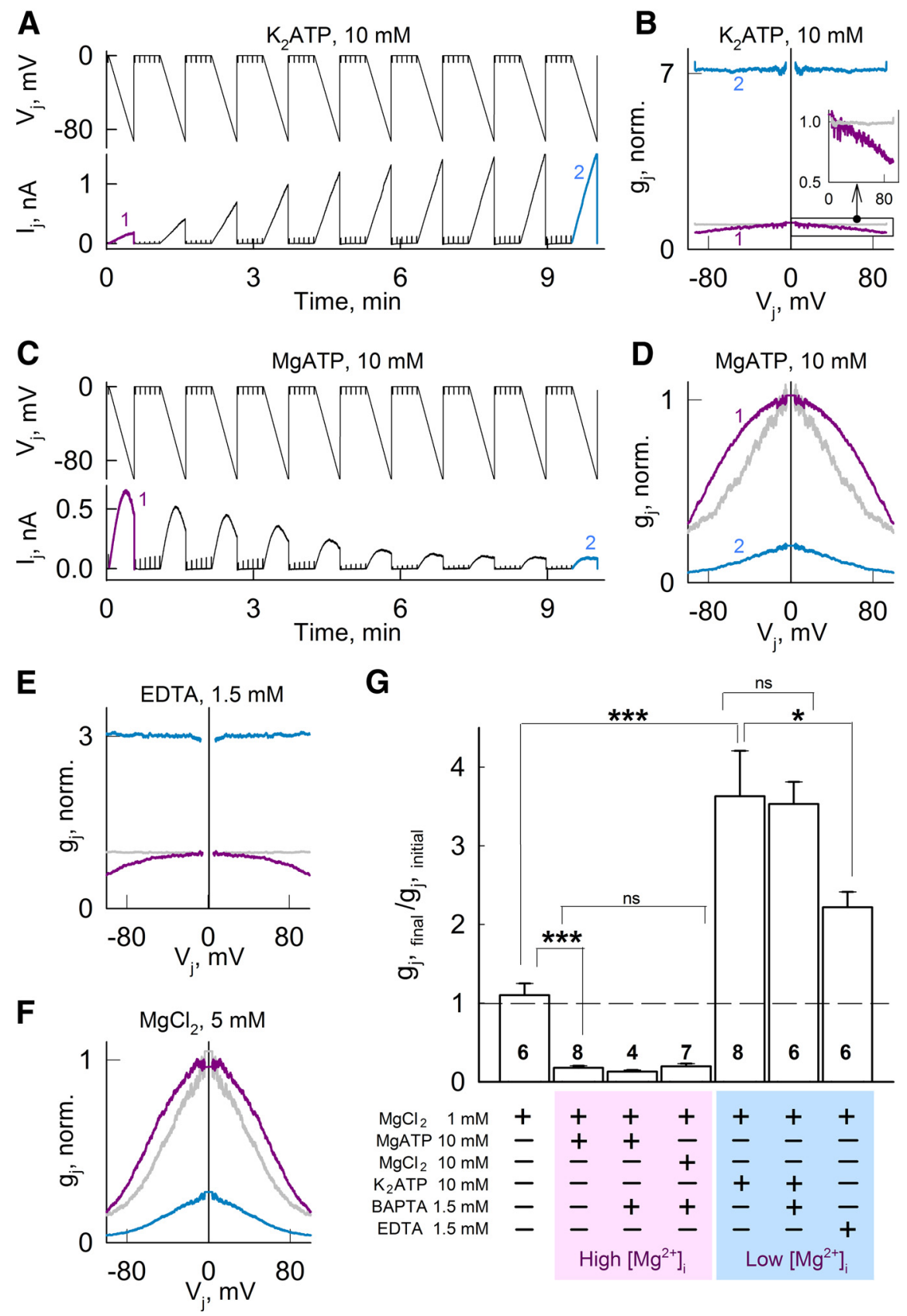

Figure 4. Intracellular $K_{2}$ ATP and MgATP have opposite effects on $g_{\mathrm{j}}$ and $V_{\mathrm{j}}$-gating in HeLa cells expressing (x36-EGFP GJ channels. $A$, $C, l_{j}$ s recorded during repeated 35 -s-long $V_{j}$ ramps from 0 to $-100 \mathrm{mV}$. Brief voltage steps of $-10 \mathrm{mV}$ were used to measure $g_{\mathrm{j}}$ in between $V_{\mathrm{j}}$ ramps. Pipette solutions contained $10 \mathrm{~mm} \mathrm{~K}_{2} \operatorname{ATP}(\boldsymbol{A})$ or MgATP $(\boldsymbol{C}) \cdot \boldsymbol{B}, \boldsymbol{D}$, First (purple) and last (cyan) $g_{\mathrm{j}}-V_{\mathrm{j}}$ relations (normalized to initial $g_{\mathrm{j}}$ value at $V_{\mathrm{j}}=0$ ) measurements obtained from experiments shown in $\boldsymbol{A}$ and $\boldsymbol{C}$, respectively. $\boldsymbol{E}, \boldsymbol{F}$, First (purple) and last (cyan) $g_{\mathrm{j}}-V_{\mathrm{j}}$ relations (normalized to initial $g_{\mathrm{j}}$ at $V_{\mathrm{j}}=0$ ) obtained using the same $V_{\mathrm{j}}$ protocol as in $A$. Pipette solutions contained $1.5 \mathrm{~mm} E D T A(E)$ or $5 \mathrm{~mm}$ $\mathrm{MgCl}_{2}(\boldsymbol{F})$. In all $g_{\mathrm{j}}-V_{\mathrm{j}}$ plots, we assumed that the $g_{\mathrm{j}}-V_{\mathrm{j}}$ relation for $V_{\mathrm{j}}>0$ was the mirror image of that for $V_{\mathrm{j}}<0$ (i.e., symmetrical around $V_{\mathrm{j}}=0$ ) and the last $g_{\mathrm{j}}-V_{\mathrm{j}}$ plots normalized to $g_{\mathrm{j}}$ at $V_{\mathrm{j}}=0$ (gray) are also shown for comparison. $G$, Changes in normalized $g_{\mathrm{j}}$ for the different compositions of the pipette solutions shown at the bottom. Values were obtained from the ratios of the steady-state final $g_{\mathrm{j}}$ to the initial $g_{\mathrm{j}}$. Numbers of independent experiments are shown in the histogram bars; ${ }^{*} p<0.05$; ${ }^{* *} p<0.001$; ns, nonsignificant $p$ values.

reduction in conductance at $V_{\mathrm{j}} \approx 0$ of $\mathrm{Cx} 43$ and $\mathrm{Cx} 47$ GJs by $\left[\mathrm{Mg}^{2+}\right]_{\mathrm{p}}=5 \mathrm{mM}$ results from a reduction of $N_{\mathrm{F}}$ without changes in $\gamma_{\text {open }}$.

Intracellular ATP-dependent modulation of junctional conductance and voltage-gating of Cx36 GJs

Adding $\mathrm{K}_{2} \mathrm{ATP}$ to the pipette solution, which reduces free $\left[\mathrm{Mg}^{2+}\right]_{\mathrm{p}}$, or adding MgATP to the pipette solution, which in- 

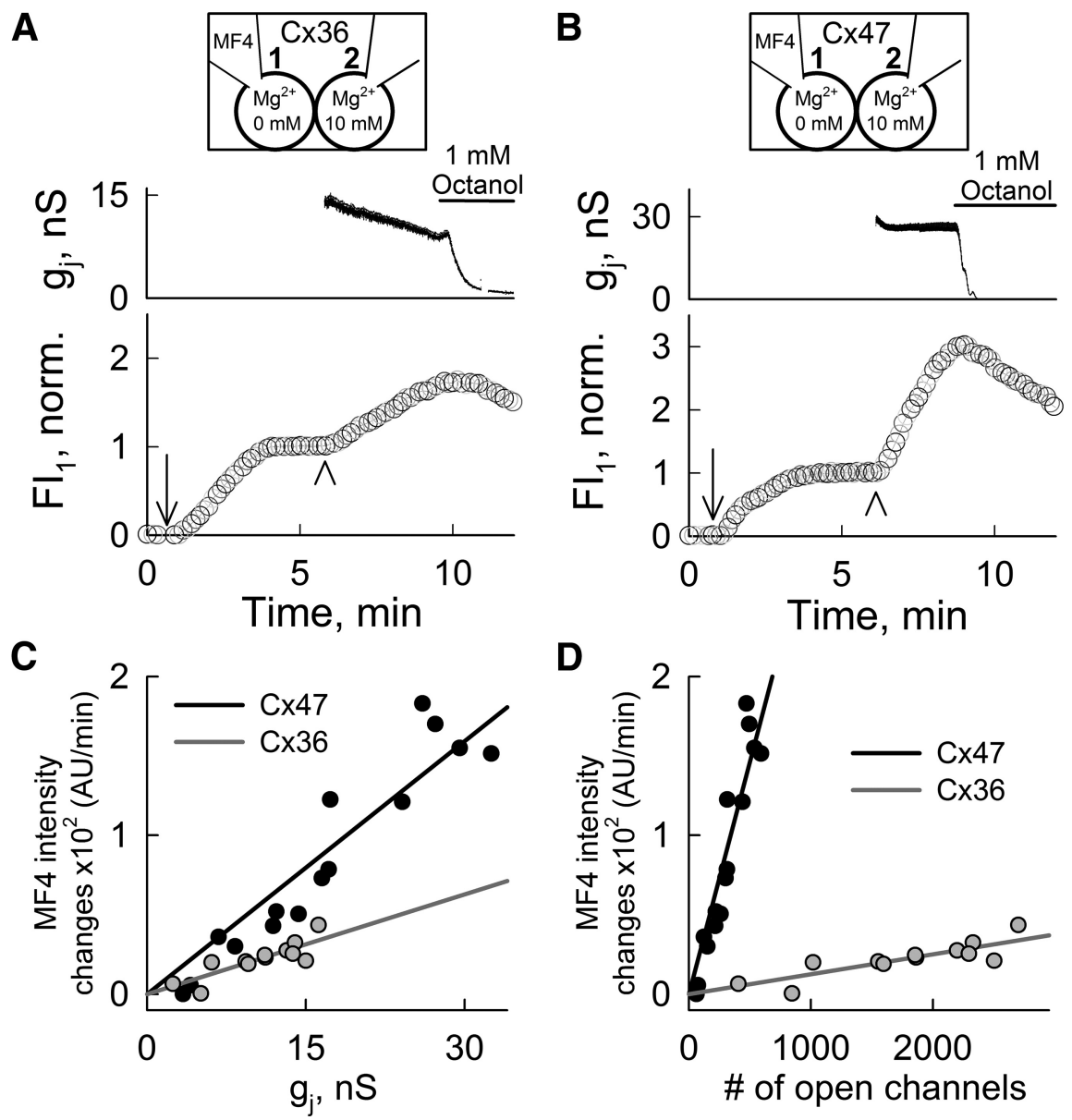

Figure 5. Permeation of $\mathrm{C} \times 36$ or $\mathrm{C} \times 47 \mathrm{GJ}$ channels by $\mathrm{Mg}^{2+}$ ions. $\boldsymbol{A}, \boldsymbol{B}$, Mag-fluo-4 (MF4) fluorescence intensity measured in cell-1 $\left(\mathrm{FI}_{1}\right)$ of HeLa $\mathrm{Cx36-EGFP}(\boldsymbol{A})$ and HeLa $\mathrm{CX} 47-\mathrm{EGFP}(\boldsymbol{B})$ cell pairs increased after opening the patch in cell-1 (arrow). After $\mathrm{FI}_{1}$ reached a plateau (normalized to this value), pipette- 2 was opened (arrowhead) and $\mathrm{Fl}_{1}$ again increased. Pipette-1 contained 50 $\mu \mathrm{M}$ MF4 and zero $\mathrm{MgCl}_{2}$, and pipette- 2 contained $10 \mathrm{~mm} \mathrm{MgCl}$ (top diagram). The $g_{\mathrm{j}}$ measurements were started after patch opening in cell-2 (top). $\mathrm{Fl}_{1}$ and $g_{\mathrm{j}}$ decreased after bath application of the $\mathrm{GJ}$ blocker octanol $(1 \mathrm{mM})$; decrease in $\mathrm{Fl}_{1}$ is ascribable to loss of $\mathrm{Mg}^{2+}$ into pipette-1. C, D, Rates of $\mathrm{FI}_{1}$ changes in HeLa (X36-EGFP (gray; $n=12$ ) and HeLa (X47-EGFP (black; $\left.n=15\right)$ cell pairs measured after patch opening in cell-2 and plotted over $g_{\mathrm{j}}(\boldsymbol{C})$ or the calculated number of open channels $(\boldsymbol{D})$. Gray and black lines are linear regressions for Cx36-EGFP $\left(R^{2}=0.71\right)$ and CX47-EGFP $\left(R^{2}=0.9\right)$ data, respectively.

creases free $\left[\mathrm{Mg}^{2+}\right]_{\mathrm{p}}$ (Lüthi et al., 1999), replicated results obtained with low or high free $\left[\mathrm{Mg}^{2+}\right]_{\mathrm{p}}$, respectively (Table 1, solutions) (Fig. 1). Indeed, adding $10 \mathrm{mM} \mathrm{K}_{2}$ ATP to pipette solution with $\mathrm{MgCl}_{2}=1 \mathrm{~mm}$ (see Materials and Methods) increased $g_{\mathrm{j}}$ (Fig. $4 A, G$ ) and decreased its sensitivity to $V_{\mathrm{j}}$ (Fig. $4 B$ ). Similar results were obtained when $\left[\mathrm{Mg}^{2+}\right]_{\mathrm{p}}$ was reduced by adding the $\mathrm{Mg}^{2+}$ chelator EDTA (Fig. $4 E$ ). In contrast, addition of $10 \mathrm{~mm}$ MgATP, which increases free $\mathrm{Mg}^{2+}$ (Lüthi et al., 1999), decreased $g_{\mathrm{j}}$ (Fig. $4 C, G$ ) and increased its sensitivity to $V_{\mathrm{j}}$ (Fig. 4D). Similar results were obtained by adding $5 \mathrm{~mm} \mathrm{MgCl}_{2}$ (Fig. $4 F$ ). These results show that low free $\mathrm{Mg}^{2+}$ conditions obtained by adding $\mathrm{K}_{2} \mathrm{ATP}$, or high free $\mathrm{Mg}^{2+}$ conditions obtained by adding MgATP, have a marked effect on $g_{\text {j }}$. Addition of 1.5 mM BAPTA to solutions with $\mathrm{K}_{2} \mathrm{ATP}$ or MgATP to minimize changes in $\left[\mathrm{Ca}^{2+}\right]_{\mathrm{p}}$ showed no differences (Fig. $4 G$ ). In summary, we attribute the effect of ATP on $g_{\mathrm{j}}$ of Cx36 GJs mainly to its capacity to modify $\left[\mathrm{Mg}^{2+}\right]_{\mathrm{i}}$.

\section{Magnesium ions permeate $\mathrm{Cx} 36$ and $\mathrm{Cx} 47 \mathrm{GJ}$ channels}

To determine whether $\mathrm{Mg}^{2+}$ permeates GJ channels and discard the hypothesis of a physical occlusion of the channel pore, we used a cell-impermeant fluorescent $\mathrm{Mg}^{2+}$ indicator (Mag-Fluo-4 or MF4) in HeLa Cx36-EGFP or Cx47EGFP cell pairs. First, we opened the patch in cell-1 (Fig. $5 A, B$, arrows) with a pipette containing $50 \mu \mathrm{M} \mathrm{MF} 4$ and nominally zero $\left[\mathrm{Mg}^{2+}\right]_{\mathrm{p}}$. Fluorescence intensity in cell-1 $\left(\mathrm{FI}_{1}\right)$, increased to a plateau, presumably corresponding to a low $\left[\mathrm{Mg}^{2+}\right]_{\mathrm{i}}$ due to loss into pipette- 1 and basal fluorescence of MF4. Then, we opened the patch in cell-2 (Fig. 5A,B, arrowheads) connecting it to a pipette containing 10 $\mathrm{mm} \mathrm{MgCl}_{2}$ and measured $\mathrm{FI}_{1}$ and $g_{\mathrm{j}}$ (top) determined by applying repeated smallamplitude $V_{\mathrm{j}}$ ramps (same as in Fig. $1 A$ ). $\mathrm{FI}_{1}$ rapidly increased indicating flux of $\mathrm{Mg}^{2+}$ from cell- 2 to cell- 1 . When the GJ blocker octanol was applied, $g_{\mathrm{j}}$ and $\mathrm{FI}_{1}$ decreased due to the closure of GJs between cell- 1 and cell- 2 and diffusion of $\mathrm{Mg}^{2+}$ into pipette-1 (Fig. $5 A, B$ ). For different pair of cells, the rate of increase of $\mathrm{FI}_{1}$ (measured in AUs for the first $2 \mathrm{~min}$ after breaking into cell-2) was proportional to $g_{\mathrm{j}}$ for both $\mathrm{Cx} 36$ and $\mathrm{Cx} 47$ and approximately half as fast per unit $g_{\mathrm{j}}$ for $\mathrm{Cx} 36$ as for $\mathrm{Cx} 47$ (Fig. 5C). The same flux data were plotted as a function of the number of open channels obtained by dividing $g_{\mathrm{j}}$ by $\gamma_{\mathrm{open}}$ of Cx36 [although we could not reliably measure $\gamma_{\text {open }}$ for Cx36, we used the published value of $6 \mathrm{pS}$ (Moreno et al., 2005) ] and Cx47 [ $\gamma_{\text {open }}=55$ pS (Teubner et al., 2001)]; for these values of $\gamma_{\text {open }}$, the per channel flux for Cx36 was approximately one-twentieth of that for $\mathrm{Cx} 47$ (Fig. 5D). In summary, Cx36 and Cx47 GJ channels are permeable to $\mathrm{Mg}^{2+}$, and the $\mathrm{Mg}^{2+}$ flux per $\mathrm{nS} g_{\mathrm{j}}$ for $\mathrm{Cx} 47$ was approximately twice that for $\mathrm{Cx} 36$. For comparison, the ratio of $\gamma_{\text {open }}$ of $\mathrm{Cx} 36$ to $\gamma_{\text {open }}$ of $\mathrm{Cx} 47$, which are presumably $\mathrm{K}^{+}$-dominated, is $\sim 1: 10$.

Transjunctional asymmetry of free magnesium ions results in asymmetric voltage-gating of Cx36 GJs

Since $\mathrm{Mg}^{2+}$ ions permeate Cx36 GJ channels, $V_{\mathrm{j}}$ applied to GJs with differing $\mathrm{Mg}^{2+}$ concentration on the two sides will alter the $\mathrm{Mg}^{2+}$ distribution within the channel through ionophoresis. Relative positivity in the cell with lower $\left[\mathrm{Mg}^{2+}\right]_{\mathrm{i}}$ will decrease the $\mathrm{Mg}^{2+}$ occupancy of the channel. If the sensorial domain for $\mathrm{Mg}^{2+}$ is located within the channel lumen, relative positive $V_{\mathrm{j}}$ on the lower $\left[\mathrm{Mg}^{2+}\right]_{\mathrm{i}}$ side should decrease $V_{\mathrm{j}}$-gating sensitivity of fast gates and increase $P_{\mathrm{oF}}$. The opposite changes should occur with relative negativity in the cell with lower $\left[\mathrm{Mg}^{2+}\right]_{\mathrm{i}}$. In homotypic Cx36 GJs, with a gradient of $\left[\mathrm{Mg}^{2+}\right]_{\mathrm{p}}(0.01 \mathrm{~mm}$ in pipette- 1 and $5 \mathrm{~mm}$ in pipette-2), relative positive $V_{\mathrm{j}}$ on the lower $\left[\mathrm{Mg}^{2+}\right]$ side increased $g_{\mathfrak{j}}$, while relative negative $V_{\mathrm{j}}$ on the lower $\left[\mathrm{Mg}^{2+}\right]$ side decreased $g_{\mathrm{j}}$ (Fig. $6 A, B$ ). The changes in $g_{\mathrm{j}}$ were independent of which pipette received the voltage (Fig. $6 D, E$ ). Decrease in $g_{j}$ during relative negativity on the lower $\left[\mathrm{Mg}^{2+}\right]$ side implies that the electric field increases $\mathrm{Mg}^{2+}$ occupancy of Cx36 channels, while increase in $g_{j}$ during relative positivity on the same side implies that the field decreases $\mathrm{Mg}^{2+}$ occupancy. Thus, transjunctional asymmetry of $\left[\mathrm{Mg}^{2+}\right]_{\mathrm{i}}$ resulted in an asymmetric $g_{\mathrm{j}}-V_{\mathrm{j}}$ 
relationship, probably involving sensitivity to both $V_{\mathrm{j}}$ and $\mathrm{Mg}^{2+}$. Asymmetric $g_{\mathrm{j}}-V_{\mathrm{j}}$ dependence could also be achieved by having MgATP or $\mathrm{K}_{2} \mathrm{ATP}$ in one pipette to increase or reduce $\left[\mathrm{Mg}^{2+}\right]_{\mathrm{i}}$, respectively, on one side of the junction (Fig. 6C,F).

To test whether $V_{\mathrm{j}}$-gating asymmetry caused by a $\left[\mathrm{Mg}^{2+}\right]_{\mathrm{i}}$ gradient is reversible, we performed an experiment in which pipette-2 containing relatively high $\left[\mathrm{Mg}^{2+}\right]_{\mathrm{p}}$ (MgATP, $3 \mathrm{~mm}$ ) was replaced by a pipette containing low $\left[\mathrm{Mg}^{2+}\right]_{\mathrm{p}}\left(\mathrm{K}_{2} \mathrm{ATP}, 5\right.$ $\mathrm{mM}$ ), and then replaced again by a pipette containing the original solution, high $\left[\mathrm{Mg}^{2+}\right]_{\mathrm{p}}$ (MgATP, $3 \mathrm{~mm}$ ) (Fig. 7A). Pipette-1 contained standard pipette solution $\left(\mathrm{MgCl}_{2}=1 \mathrm{~mm}\right)$ throughout the experiment. During the first $8 \mathrm{~min}, g_{j}$ decreased, resulting in a $g_{\mathrm{j}}-V_{\mathrm{j}}$ asymmetry with somewhat higher sensitivity to $V_{\mathrm{j}}$ at negativity on the side with standard pipette solution (Fig. $7 \mathrm{Ba}$ ). After the first exchange of pipette- $2, g_{\mathrm{j}}$ increased and $V_{\mathrm{j}}$-gating asymmetry reversed very quickly (Fig. $7 \mathrm{Bb}$ ). After the second exchange of pipette-2, $g_{j}$ decreased and $V_{\mathrm{j}}$-gating asymmetry reversed again very quickly (Fig. $7 \mathrm{Bc}$ ). In summary, $V_{\mathrm{j}}$ has a strong effect on the $\mathrm{Mg}^{2+}$ dependent modulation, suggesting a presence within the channel lumen of a sensorial domain for $\mathrm{Mg}^{2+}$.

The capability of $V_{\mathrm{j}}$ steps of alternating polarity to induce closures and openings of Cx36 GJ channels under a transjunctional concentration gradient of $\mathrm{Mg}^{2+}$ in tens of seconds (Fig. $6 A, D)$ and reversal of $g_{j}-V_{j}$ asymmetry by exchange of pipette solutions (Fig. 7) indicate that the $\mathrm{Mg}^{2+}$-dependent effect on $g_{\mathrm{j}}$ is reversible. It is most likely that $g_{j}$ changes are caused by direct $\mathrm{Mg}^{2+}$ effects on channel function rather than through posttranslational modifications (no ATP in pipette solutions) or insertion/removal of channels from the junctional plaque. Furthermore, if $\mathrm{Cx} 36$ has one or more cytoplasmic $\mathrm{Mg}^{2+}$-binding sites, then the $\mathrm{Mg}^{2+}$-dependent closure of one aHC exposed to high $\left[\mathrm{Mg}^{2+}\right]_{\mathrm{i}}$ would result in $P_{\mathrm{o}}$ close to zero. We did not observe a comparable reduction in $g_{\mathrm{j}}$ at $V_{\mathrm{j}}=0$ between experiments with symmetric $\left(\left[\mathrm{Mg}^{2+}\right]_{\mathrm{p}}=5 \mathrm{mM}\right.$ in both pipettes) or asymmetric $\left(\left[\mathrm{Mg}^{2+}\right]_{\mathrm{p}}=5 \mathrm{~mm}\right.$ in pipette- $1 ; 0.01 \mathrm{mM}$ in pipette-2) $\mathrm{Mg}^{2+}$ conditions, suggesting that $\mathrm{Mg}^{2+}$ sensorial domain is not located in the cytoplasmic side of the channel. Together, these results indicate that the effect of $\mathrm{Mg}^{2+}$ is completely reversible and suggest that the site or sites of action of $\mathrm{Mg}^{2+}$ are in the channel pore-lining residues where $V_{j}$ 's affect the ionic occupancy of the channel, through ionophoresis, and possibly binding affinity.

\section{High intracellular magnesium stabilizes a closed} conformation of $\mathrm{Cx} 36 \mathrm{GJ}$ channels

To test whether $\left[\mathrm{Mg}^{2+}\right]_{\mathrm{i}}$ affects the recovery of $g_{\mathrm{j}}$ after closing Cx36 GJ channels by $V_{\mathrm{j}}$-gating, we examined changes in $g_{\mathrm{j}}$ after applying $V_{\mathrm{j}}$ steps in symmetrical $\left[\mathrm{Mg}^{2+}\right]_{\mathrm{p}}=5 \mathrm{~mm}$ (Fig. $8 A$ ). $V_{\mathrm{j}}$-gating at high $\mathrm{Mg}^{2+}$ induced a fast reduction in $g_{\mathrm{j}}$ followed by a slow continuous decay. The recovery of $g_{\mathrm{j}}$ after $V_{\mathrm{j}}$ steps showed fast and slow components (Fig. 8A), presumably due to the opening of fast and slow gates, respectively. However, the recovery of $g_{\mathrm{j}}$ did not reach values of an
B

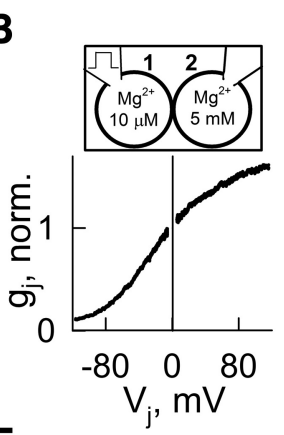

E

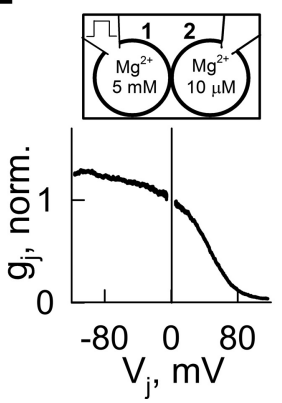

$\mathbf{F}$
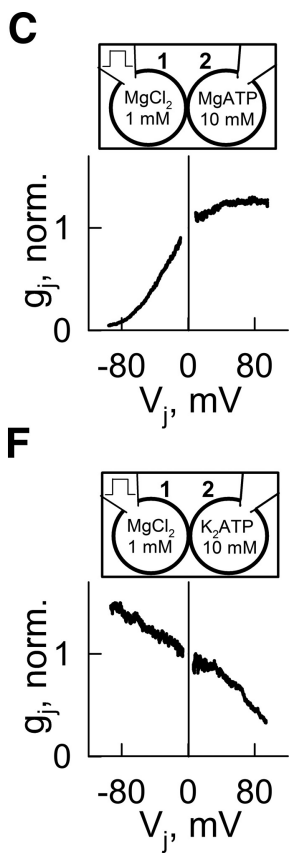

Figure 6. Transjunctional asymmetry of $\left[\mathrm{Mg}^{2+}\right]_{\mathrm{i}}$ causes asymmetric $V_{\mathrm{j}}$ gating of homotypic $(\times 36-\mathrm{EGFP}$ GJs. $\boldsymbol{A}, \boldsymbol{D}$, Transjunctional asymmetry in $\left[\mathrm{Mg}^{2+}\right]_{\mathrm{i}}$ (see diagrams at the top of $\boldsymbol{B}$ and $\boldsymbol{E}$ for free $\mathrm{Mg}^{2+}$ concentration in pipette solutions and stimulation measured $g_{\mathrm{j}}$ between $V_{\mathrm{j}}$ steps. $\boldsymbol{B}, \boldsymbol{E}, g_{\mathrm{j}}-V_{\mathrm{j}}$ relations (normalized to $g_{\mathrm{j}}$ value at $V_{\mathrm{j}}=0$ ) measured by applying long $(60 \mathrm{~s}) V_{\mathrm{j}}$ ramps from 0 to +100 and $-100 \mathrm{mV}$. Relative positivity on the high $\left[\mathrm{Mg}^{2+}\right]$ side decreased $g_{\mathrm{j}}$., $\boldsymbol{F}$, Asymmetric concentration of MgATP ( $\boldsymbol{C}$, top diagram) or $\mathrm{K}_{2} \mathrm{ATP}\left(\boldsymbol{F}\right.$, top diagram) was associated with asymmetry of $g_{\mathrm{j}}-V_{\mathrm{j}}$ dependence (normalized to $g_{\mathrm{j}}$ value at $V_{\mathrm{j}}=0$ ).

averaged curve of $g_{\mathrm{j}}$ decay obtained in the absence of $V_{\mathrm{j}}$ steps (Fig. $8 A$, dashed line). These results indicate that increasing $V_{\mathrm{j}}$-gating and the $\mathrm{Mg}^{2+}$ occupancy by $V_{\mathrm{j}}$-dependent ionophoresis in Cx36 GJ channels increased the speed of the $\mathrm{Mg}^{2+}$-dependent reduction in $g_{\mathrm{j}}$. Moreover, at $\left[\mathrm{Mg}^{2+}\right]_{\mathrm{p}}=5 \mathrm{~mm}$, the values of $g_{\mathrm{j}}$ obtained using $V_{\mathrm{j}}$ steps to accelerate the decay were smaller than those obtained at the same $\left[\mathrm{Mg}^{2+}\right]_{\mathrm{p}}$ without using $V_{\mathrm{j}}$ steps, suggesting that high $\mathrm{Mg}^{2+}$ could stabilize a closed conformation, possibly of slow gates. We were not able to assess $g_{\mathrm{j}}$ recovery after $V_{\mathrm{j}}$-gating in low $\left[\mathrm{Mg}^{2+}\right]_{\mathrm{p}}$ due to the lack of $V_{\mathrm{j}}$-sensitivity (Fig. 1).

To close Cx36 GJ channels at $V_{\mathrm{j}}=0$, we used the chemical uncoupler decanol $(0.5 \mathrm{~mm})$ and examined $g_{\mathrm{j}}$ recovery during washout at different $\left[\mathrm{Mg}^{2+}\right]_{\mathrm{p}}($ Fig. $8 \mathrm{~B})$. These experiments were normalized to $g_{\mathrm{j}}$ values after reaching the steady state $\left(g_{\mathrm{j}, \mathrm{ss}}\right)$ at each $\left[\mathrm{Mg}^{2+}\right]_{\mathrm{p}}$ ( $\sim 20 \mathrm{~min}$ after opening patches), and time 0 was adjusted to the beginning of decanol perfusion. Decanol was applied until $g_{\mathrm{j}}$ neared zero and then washed out with normal bath solution. Full recovery of $g_{\mathrm{j}}$ was reached only at $\left[\mathrm{Mg}^{2+}\right]_{\mathrm{p}}=0.01 \mathrm{~mm}$ (Fig. $8 \mathrm{Ba})$. Recovery of $g_{\mathrm{j}}$ was $\sim 50 \%$ at $\left[\mathrm{Mg}^{2+}\right]_{\mathrm{p}}=1 \mathrm{mM}($ Fig. $8 \mathrm{Bb})$ and $\sim 25 \%$ at $\left[\mathrm{Mg}^{2+}\right]_{\mathrm{p}}=5 \mathrm{~mm}$ (Fig. $8 \mathrm{Bc}$ ). A possible explanation for these results is that binding of $\mathrm{Mg}^{2+}$ in the Cx36 GJ channels stabilizes a closed conformation, explaining the low recovery of $g_{j}$ after closing the channels with $V_{\mathrm{j}}$-gating or chemical-gating under high $\left[\mathrm{Mg}^{2+}\right]_{\mathrm{p}}$.

\section{A phosphomimetic mutant of $\mathrm{Cx} 36$ shows magnesium- dependent modulation of junctional conductance similar to Cx36 wild type}

Function of Cx36 GJs strongly depends on phosphorylation of two intracellular serine residues, which are phosphorylated by CaMKII, cGMP-dependent protein kinase, and cAMPdependent protein kinase (Mitropoulou and Bruzzone, 2003; 


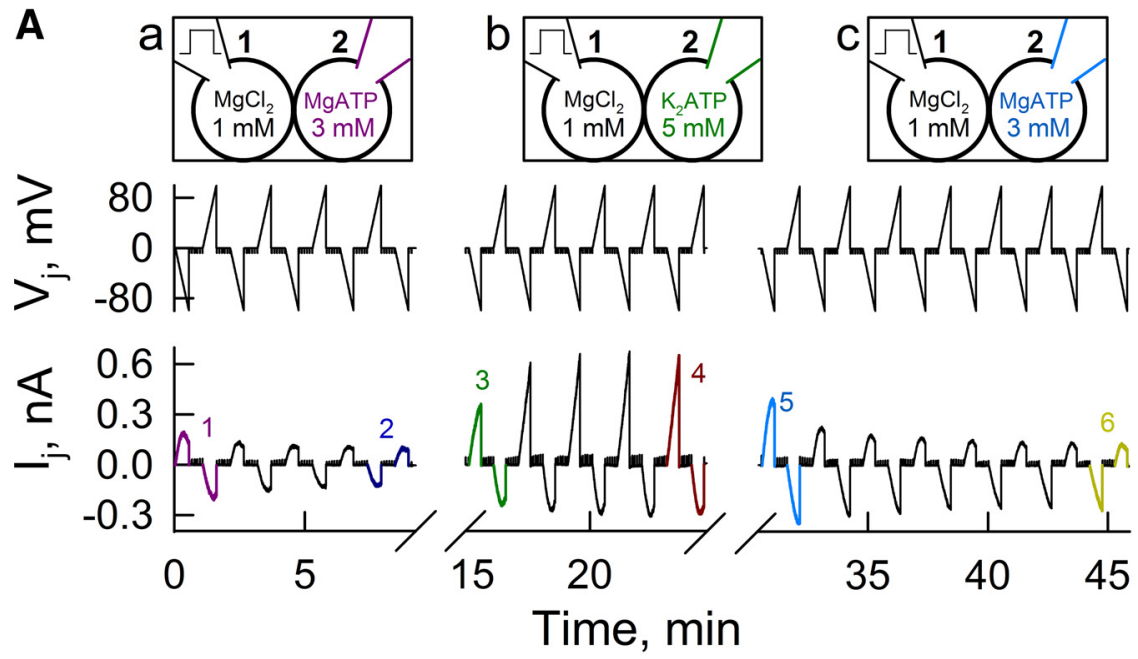

B
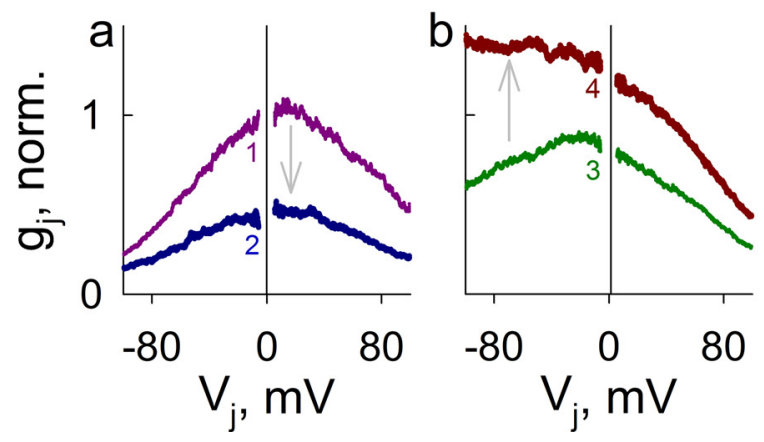

Figure 7. Fast reversal of asymmetric $g_{\mathrm{j}}-V_{\mathrm{j}}$ dependence by reversal of transjunctional gradient of $\left[\mathrm{Mg}^{2+}\right]_{\mathrm{i}} \cdot \boldsymbol{A}_{,}$Changes in $I_{\mathrm{j}}$ during consecutive 35 -s-long $V_{\mathrm{j}}$ ramps from 0 to $-100 \mathrm{mV}$ and from 0 to $100 \mathrm{mV}$. Initially, cell-1 was loaded with a control/ standard pipette solution $\left(\mathrm{MgCl}_{2}, 1 \mathrm{~mm}\right)$ and cell-2 contained $\operatorname{MgATP}(\boldsymbol{A a})$. From $\sim 9$ to 14 min after onset, pipette-2 was carefully detached and replaced with a pipette containing $\mathrm{K}_{2} \mathrm{ATP}(\boldsymbol{A} \boldsymbol{b})$ reversing the $\mathrm{Mg}^{2+}$ gradient. From $\sim 25$ to 30 min after onset, pipette- 2 was replaced with a pipette containing MgATP $(\boldsymbol{A C})$ reversing the $\mathrm{Mg}^{2+}$ gradient once again. $\boldsymbol{B}, g_{\mathrm{j}}-V_{\mathrm{j}}$ plots (normalized to initial $g_{\mathrm{j}}$ value at $V_{\mathrm{j}}=0$ ) from ramp pairs in $(\boldsymbol{A})$ designated with numbers 1 and $2(\boldsymbol{B a}), 3$ and $4(\boldsymbol{B} \boldsymbol{b})$, and 5 and $6(\boldsymbol{B C})$.

Ouyang et al., 2005; Patel et al., 2006; Alev et al., 2008; Kothmann et al., 2009). Furthermore, phosphatases are highly dependent on $\left[\mathrm{Mg}^{2+}\right]_{\mathrm{i}}$ (Merlevede et al., 1984). Therefore, we tested whether changes in phosphorylation of Cx36 might be involved in the observed $\mathrm{Mg}^{2+}$-dependent changes of $g_{j}$. For these tests, we used mutants of Cx36 in which serines 110 and 293 were replaced by aspartates, which resemble negatively charged phosphoserine residues. These "phosphomimetic" mutants are locked in a pseudophosphorylated state that cannot be dephosphorylated, thus allowing study of $\mathrm{Mg}^{2+}$-dependent modulation of $g_{\mathrm{j}}$ independently of phosphorylation or dephosphorylation at these sites. We found that combined point mutations, S110D and S293D, exhibited slightly more increase in $g_{j}$ at low $\left[\mathrm{Mg}^{2+}\right]_{i}$ and slightly less decay of $g_{\mathrm{j}}$ at high $\left[\mathrm{Mg}^{2+}\right]_{\mathrm{i}}$. However, in neither case were the values significantly different from those measured in $\mathrm{Cx} 36$. In summary, these phosphomimetic mutants behave similarly to the wild-type $\mathrm{Cx} 36$, suggesting that changes in phosphorylation of at least these two serine residues are not involved in the $\mathrm{Mg}^{2+}$ dependent modulation of $g_{\mathrm{j}}$.

\section{Modulation of junctional conductance by different divalent cations in Cx36 GJ channels}

To rule out a possible nonspecific effect of surface charge screening and test the specificity of the effects of $\mathrm{Mg}^{2+}$ ions on $\mathrm{Cx} 36$, we examined $g_{\mathrm{j}}$ using pipette solutions containing divalent cations from alkaline earth metals $\left(\mathrm{Ca}^{2+}\right.$ or $\left.\mathrm{Ba}^{2+}\right)$ or transition metals

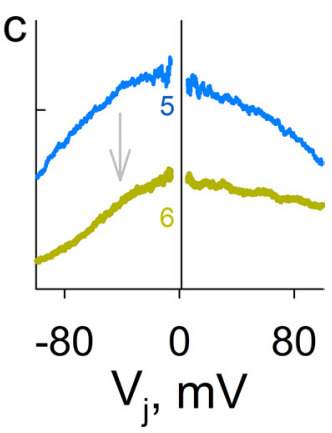

$\left(\mathrm{Mn}^{2+}, \mathrm{Cd}^{2+}\right.$, or $\left.\mathrm{Zn}^{2+}\right)$. Because EGTA and BAPTA are not good buffers for all these divalents (Patton et al., 2004), we prepared solutions without EGTA or BAPTA and compared results with a control solution of nominally zero divalents (see Materials and Methods). The control solution increased $g_{\mathrm{j}}$ to $\sim 2.5$-fold of initial $g_{\mathrm{j}}$ (Fig. 9). All divalents at a concentration of $2 \mathrm{~mm}$ decreased $g_{\mathrm{j}}$ (Fig. $9 A, B$ ), but with different times to reach $5 \%$ of initial $g_{\text {j }}$ (Fig. $9 A, C$ ), indicating that nonspecific screening of charges in the membrane surface and/or cytoplasmic side of the Cx36 protein does not play a major role in this inhibition. Because $2 \mathrm{~mm} \mathrm{Zn}^{2+}$ produced the fastest inhibition, we used solutions with $0.2 \mathrm{mM} \mathrm{Zn}^{2+}$ to compare the degree of inhibition and time to reach the steady state. Interestingly, $0.2 \mathrm{~mm} \mathrm{Zn}^{2+}$, like $2 \mathrm{~mm} \mathrm{Zn}^{2+}$, almost completely blocked $g_{\mathrm{j}}$ (Fig. 9A,B), but took five times longer to reach $5 \%$ of initial $g_{\mathrm{j}}$ (Fig. $9 A, C$ ). In summary, all examined divalent cations strongly inhibited conductance of Cx36 GJs but with different kinetics. These results suggest that divalent cations act through a relatively nonspecific negatively charged binding site in Cx36 rather than through surface charge screening.

\section{Intracellular magnesium-dependent modulation of junctional conductance in neurons of the MesV nucleus}

To test whether native electrical synapses expressing Cx36 are sensitive to changes in $\left[\mathrm{Mg}^{2+}\right]_{\mathrm{i}}$, we examined changes in the strength of electrical coupling by measuring junctional conductance $\left(G_{\mathrm{j}}\right)$ between pairs of MesV neurons at low or high $\left[\mathrm{Mg}^{2+}\right]_{\mathrm{i}}$. The MesV nucleus is formed by the somata of primary afferents originating in jaw-closing muscles whose cell bodies are located within the CNS rather than peripheral ganglia (Nagy et al., 1986). These large somata (Fig. 10A) are electrically coupled through Cx36-containing somato-somatic GJs (Curti et al., 2012). We recorded from pairs of $\mathrm{MesV}$ under current-clamp configuration, and $G_{\mathrm{j}}$ was indirectly estimated using interleaved hyperpolarizing current steps on each cell (see Materials and Methods) (Fig. 10B). When recording with a solution containing $\left[\mathrm{Mg}^{2+}\right]_{\mathrm{p}}=0.01 \mathrm{~mm}$ in both pipettes, we observed a progressive increase in $G_{j}$ following patch opening (Fig. 10C). In contrast, solutions containing $\left[\mathrm{Mg}^{2+}\right]_{\mathrm{p}}=5 \mathrm{~mm}$ produced a progressive reduction of $G_{\mathrm{j}}$ (Fig. 10C). Averaged $G_{\mathrm{j}}$ (normalized to initial values) showed that low $\left[\mathrm{Mg}^{2+}\right]_{\mathrm{i}}$ led to a $18 \pm 4 \%$ increase in $G_{\mathrm{j}}$ after $\sim 10 \mathrm{~min}$ of patch opening, whereas high $\left[\mathrm{Mg}^{2+}\right]_{\mathrm{i}}$ produced a $21 \pm 3 \%$ reduction (Fig. $10 D)$. Longer-lasting $(\sim 30 \mathrm{~min})$ experiments with $5 \mathrm{~mm}\left[\mathrm{Mg}^{2+}\right]_{\mathrm{i}}$ showed further reductions in $G_{j}$ ( $>30 \%$; data not shown). Thus, native Cx36-containing electrical synapses exhibited similar sensitivity to $\left[\mathrm{Mg}^{2+}\right]_{\mathrm{i}}$, suggesting that this mechanism could operate in vivo.

\section{Discussion}

Although effects of divalent cations on GJ channels have long been recognized (Loewenstein, 1967; Délèze and Loewenstein, 
A

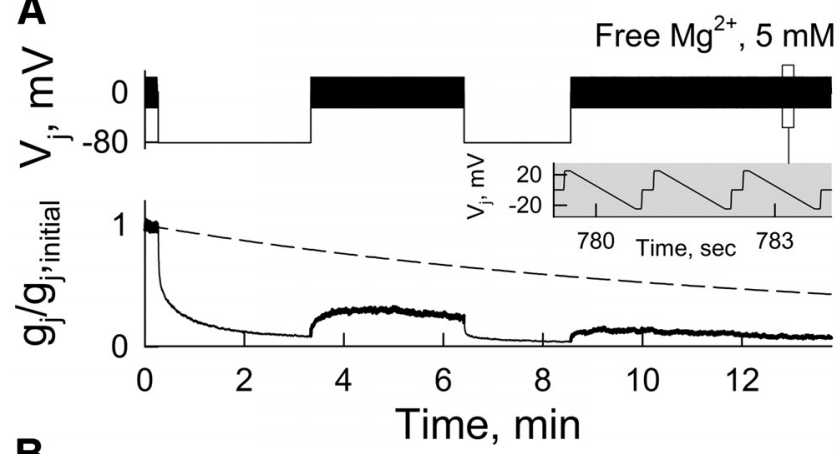

B
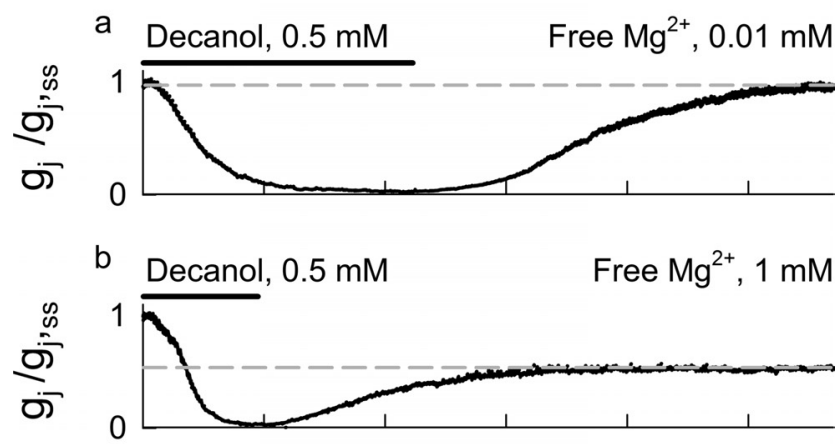

C Decanol, $0.5 \mathrm{mM}$

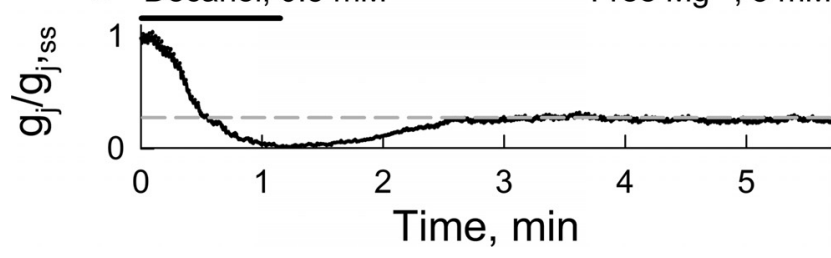

Figure 8. Recovery of $g_{\mathrm{j}}$ after decrease induced by $V_{\mathrm{j}}$-gating or chemical-gating depends on $\left[\mathrm{Mg}^{2+}\right]_{\mathrm{i}} \cdot \boldsymbol{A}$, Bottom, Dynamics of $g_{\mathrm{j}}$ recovery (normalized to initial $g_{\mathrm{j}}$ value) after $V_{\mathrm{j}}$ steps $(-80$ $\mathrm{mV}$; top) at $\left[\mathrm{Mg}^{2+}\right]_{\mathrm{p}}=5 \mathrm{~mm}$. Small-amplitude repeated $V_{j}$ ramps ( $\pm 21 \mathrm{mV}, 1.3 \mathrm{~s}$; inset) were used to measure $g_{j}$ before and after $V_{j}$ steps. Dashed line represents averaged decay in $g_{j}$ in the absence of $V_{j}$ steps using pipette solutions with $\left[\mathrm{Mg}^{2+}\right]_{p}=5 \mathrm{~mm}$. $\boldsymbol{B}$, Dynamics of $g_{\mathrm{j}}$ recovery normalized to steady-state $g_{\mathrm{j}}$ value $\left(g_{\mathrm{j} \text { 'ss }}\right)$ before decanol $(0.5 \mathrm{~mm})$ application to induce uncoupling at $\left[\mathrm{Mg}^{2+}\right]_{\mathrm{p}}=0.01 \mathrm{~mm}(\boldsymbol{B a}), 1 \mathrm{~mm}(\boldsymbol{B} \boldsymbol{b})$, and $5 \mathrm{~mm}(\boldsymbol{B} \boldsymbol{c})$. Small-amplitude repeated $V_{\mathrm{j}}$ ramps (same as in $\boldsymbol{A}$ ) were used to measure $g_{\mathrm{j}}$. Gray dashed lines show levels of $g_{\mathrm{j}}$ recovery during washout from decanol.

1976; Spray et al., 1982; Noma and Tsuboi, 1987; Vera et al., 1996; Matsuda et al., 2010), the mechanisms by which $\mathrm{Mg}^{2+}$ modulates Cx36 GJs have not been studied. Here we demonstrate that control/resting levels of $\left[\mathrm{Mg}^{2+}\right]_{\mathrm{i}}(\sim 1 \mathrm{~mm})$ maintain Cx36 GJ channels expressed in heterologous systems and neurons of the MesV nucleus partially inhibited and that cell-cell coupling is modulated by changes in $\left[\mathrm{Mg}^{2+}\right]_{\mathrm{i}}$. We showed that the $\mathrm{Mg}^{2+}$ dependent modulation of $g_{\mathrm{j}}$ is caused by changes of $P_{\mathrm{o}}$ and $N_{\mathrm{F}}$ (Fig. $1 G-I$ ). In Cx36, the Boltzmann parameters $A_{\mathrm{F}}$ and $A_{\mathrm{S}}$ remained relatively constant during changes in $\left[\mathrm{Mg}^{2+}\right]_{\mathrm{i}}$ (Table 2), indicating that changes in $P_{\mathrm{o}}$ at $V_{\mathrm{j}}=0$ were mainly due to changes in $V_{\mathrm{F}, \mathrm{o}}$, and that the gating charge of the $V_{\mathrm{j}}$ sensor was not modified by changes in $\left[\mathrm{Mg}^{2+}\right]_{\mathrm{i}} \cdot g_{\mathrm{j}}$ approached zero at $\left[\mathrm{Mg}^{2+}\right]_{\mathrm{p}}=$ $\sim 10 \mathrm{~mm}$, while maximal values of $g_{\mathrm{j}}$ in HeLa cells were reached by decreasing $\left[\mathrm{Mg}^{2+}\right]_{\mathrm{p}}$ to $0.01 \mathrm{~mm}$ or less (Fig. $1 E$ ). Similar effects on $g_{\mathrm{j}}$ were achieved by adding to the pipette solution $\mathrm{K}_{2} \mathrm{ATP}$ or MgATP (Fig. 4), which reduced or increased $\left[\mathrm{Mg}^{2+}\right]_{\mathrm{i}}$, respectively. These data suggest that ATP affects $g_{j}$ mainly through its capacity to modulate free $\left[\mathrm{Mg}^{2+}\right]_{\mathrm{i}}$ (Lüthi et al., 1999). In our studies, $\left[\mathrm{Ca}^{2+}\right]_{\mathrm{i}}$ was strongly buffered at low values $(\sim 25 \mathrm{nM})$
A
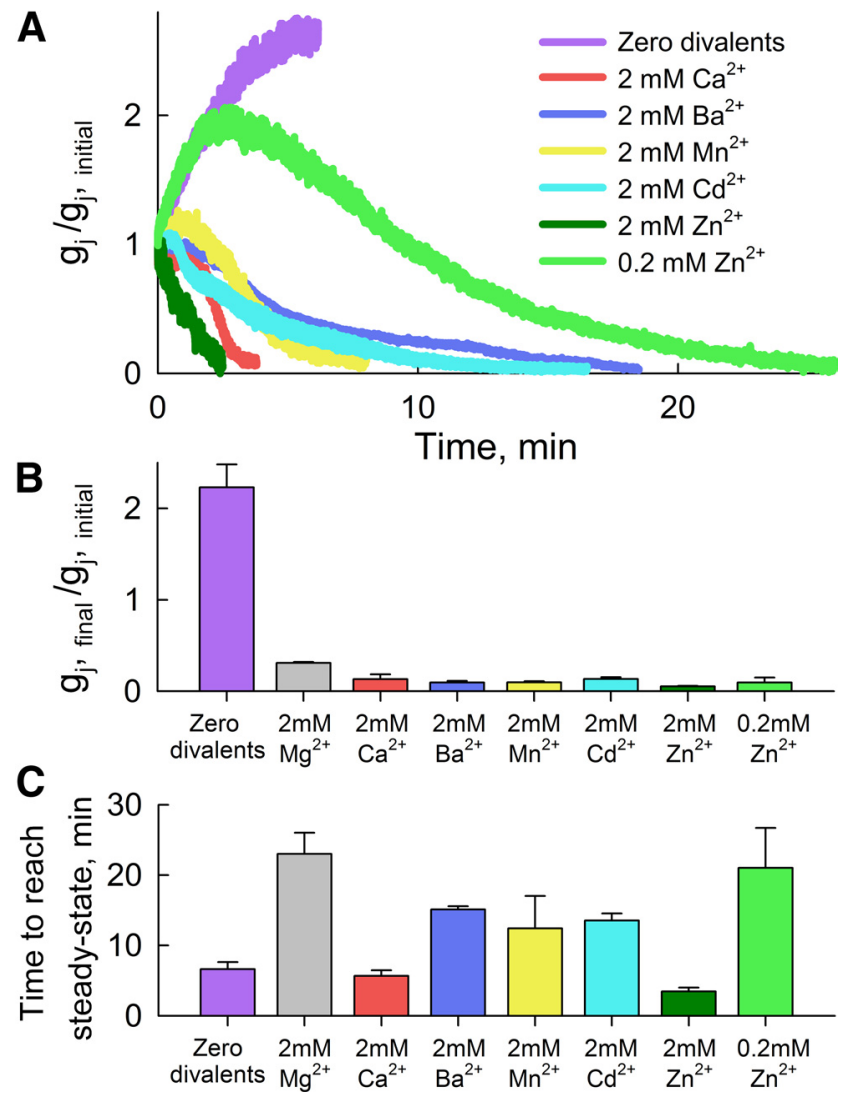

Figure 9. Divalent cations decrease $g_{\mathrm{j}}$ of $\left(x 36 \mathrm{GJ} s\right.$. $A$, Dynamics of $g_{\mathrm{j}}$ (normalized to initial $g_{\mathrm{j}}$ value) changes for different divalent cations. $\boldsymbol{B}$, Average $g_{j}$ (normalized to initial $g_{j}$ values) from experiments using pipette solution containing the following: nominally zero divalents $(n=5)$; $2 \mathrm{~mm}$ free $\mathrm{Mg}^{2+}(n=3), \mathrm{Ca}^{2+}(n=5), \mathrm{Ba}^{2+}(n=5), \mathrm{Mn}^{2+}(n=6), \mathrm{Cd}^{2+}(n=4), \mathrm{Zn}^{2+}$ $(n=3) ; 0.2 \mathrm{~mm}$ free $\mathrm{Zn}^{2+}(n=4)$. C, Average time for $g_{\mathrm{j}}$ to undergo $95 \%$ of the change from initial to virtual steady-state conductance after beginning dual whole-cell voltage clamp.

with BAPTA and EGTA, indicating that $\mathrm{Mg}^{2+}$ ions, not $\mathrm{Ca}^{2+}$ ions, were involved in the observed changes in $g_{j}$.

Our data show that high $\left[\mathrm{Mg}^{2+}\right]_{\mathrm{i}}$ also reduces $g_{\mathrm{j}}$ of GJ channels formed of Cx26, Cx32, Cx43, Cx45, and Cx47 (Fig. 2E). However, we did not observe an increase in $g_{\mathrm{j}}$ for these Cxs at $\left[\mathrm{Mg}^{2+}\right]_{\mathrm{i}}=0.01 \mathrm{~mm}$ (Fig. $2 D$ ). Thus, Cx36 was the only Cx examined that exhibited a substantial inhibition of GJ channels at control/resting levels of $\left[\mathrm{Mg}^{2+}\right]_{\mathrm{i}}$. This suggests that changes in $\left[\mathrm{Mg}^{2+}\right]_{\mathrm{i}}$ under physiological or pathological conditions can modulate preferentially Cx36-mediated cell-cell coupling. The $\gamma_{\text {open }}$ of $\mathrm{Cx} 43$ and $\mathrm{Cx} 47$ did not change under enhanced $\left[\mathrm{Mg}^{2+}\right]_{\mathrm{p}}$ (Fig. $3 L, M$ ) demonstrating that $\mathrm{Mg}^{2+}$-mediated decrease in $g_{j}$ for these Cxs was not due to reduction in $\gamma_{\text {open. }}$. GJs formed of both $\mathrm{Cx} 36$ and $\mathrm{Cx} 47$ are permeable to $\mathrm{Mg}^{2+}$ (Fig. 5); thus, $V_{\mathrm{j}}$ may modify the $\mathrm{Mg}^{2+}$ occupancy of the channel by ionophoresis and also by changing the on and off rates of $\mathrm{Mg}^{2+}$ binding. We conclude that $\mathrm{Mg}^{2+}$ acts inside the $\mathrm{Cx} 36$ channel lumen based on the following facts: (1) $\mathrm{Mg}^{2+}$ permeates the channel (Fig. 5); (2) transjunctional gradients of $\left[\mathrm{Mg}^{2+}\right]_{\mathrm{i}}$ caused asymmetric $g_{\mathrm{j}}-V_{\mathrm{j}}$ dependence (Figs. 6, 7); and (3) the averaged $g_{\mathrm{j}, \mathrm{ss}}$ at $V_{\mathrm{j}}=0 \mathrm{ob}-$ served using transjunctional asymmetric $\left[\mathrm{Mg}^{2+}\right]_{\mathrm{i}}(5 \mathrm{~mm}$ in pipette-1; $0.01 \mathrm{~mm}$ in pipette-2) is higher than averaged $g_{j, s s}$ obtained under symmetric high $\left[\mathrm{Mg}^{2+}\right]_{\mathrm{i}}(5 \mathrm{~mm}) . \mathrm{Mg}^{2+}$ dependent changes in $g_{j}$ were too fast to be explained by an insertion or removal of channels during $V_{j}$ 's of different polarities (Fig. 6) and after changes in $\left[\mathrm{Mg}^{2+}\right]_{\mathrm{i}}$ (Fig. 7). Furthermore, we 

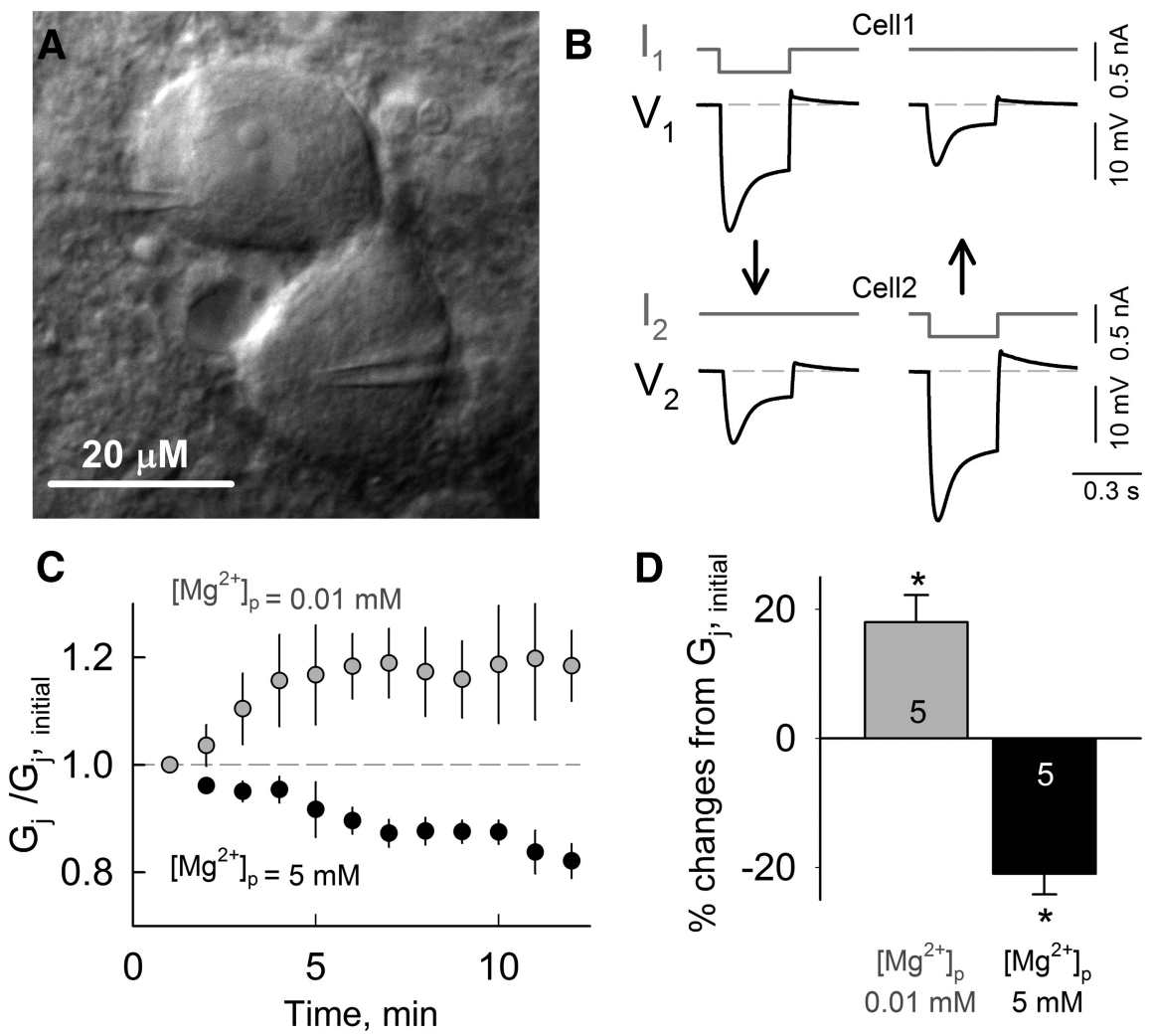

Figure 10. $\mathrm{Mg}^{2+}$-dependent modulation of $G_{\mathrm{j}}$ in pairs of MesV neurons. $A$, IR-DIC image of a pair of electrically coupled MesV neurons during dual whole-cell patch clamp. $\boldsymbol{B}$, Simultaneous current-clamp recordings from a pair of electrically coupled MesV neurons; arrows indicate the direction of the spread of electrotonic potential. Voltage traces were recorded from cell-1 and cell-2 $\left(V_{1}\right.$ and $V_{2}$, respectively) during 300 ms hyperpolarizing current steps of $-300 \mathrm{pA}$ injected either in cell-1 or in cell-2 $\left(I_{1}\right.$ and $I_{2}$, respectively). $C$, Time course of changes in mean $G_{j}$ (normalized to initial values) at $\left[\mathrm{Mg}^{2+}\right]_{p}=0.01$ (gray) and $5 \mathrm{~mm}$ (black). Each point represents an average from five independent experiments. $D$, Mean percentage changes of $G$ from initial values after $12 \mathrm{~min}$ of patch openings with $\left[\mathrm{Mg}^{2+}\right]_{\mathrm{p}}=0.01$ (gray) and $5 \mathrm{~mm}$ (black). Numbers of cell pairs are indicated within columns; ${ }^{*} p<0.05$.

did not detect changes in the size or fluorescence intensity of Cx36-EGFP junctional plaques (data not shown).

The $\mathrm{Mg}^{2+}$ occupancy of Cx36 GJ channels reduces $P_{\mathrm{oF}}$ (Fig. 1) by favoring transitions of fast gates into a closed state, and also appears to stabilize a long-lived closed conformation of slow gates (Fig. 8), which in the $\mathrm{S} 16 \mathrm{SM}$ is reflected in a reduction of $N_{\mathrm{F}}$. Low $\left[\mathrm{Mg}^{2+}\right]_{\mathrm{i}}$ conditions allowed for a full recovery of $g_{\mathrm{j}}$ from uncoupling induced by chemical-gating (Fig. $8 B$ ). However, in the presence of high $\left[\mathrm{Mg}^{2+}\right]_{\mathrm{i}}$, the recovery of $g_{\mathrm{j}}$ from uncoupling induced by chemical-gating or $V_{\mathrm{j}}$-gating was markedly reduced (Fig. $8 \mathrm{~A}, \mathrm{~B}$ ). These results suggest that $\mathrm{Mg}^{2+}$ stabilizes the closed conformation of the slow gate mediated by chemical uncouplers or $V_{\mathrm{j}}$. The relative slow kinetics of the $\mathrm{Mg}^{2+}$-dependent changes in $g_{\mathrm{j}}$ at $V_{\mathrm{j}}=0$ (Fig. $1 ; \sim 20 \mathrm{~min}$ to reach steady state) could be the combined results of a preferential binding of $\mathrm{Mg}^{2+}$ to a closed state $\left(P_{\mathrm{o}}=0.64\right.$ at $\left[\mathrm{Mg}^{2+}\right]_{\mathrm{p}}=1 \mathrm{mM}$ and $\left.V_{\mathrm{j}}=0\right)$ and a low rate of unbinding (off rate) leading to the stabilization of a closed channel conformation. In addition, Cx36 GJ channels may require coordinated binding of $\mathrm{Mg}^{2+}$ to more than one binding site to stabilize the closed channel conformation. The effect of $\mathrm{Mg}^{2+}$ on the reduction of $N_{\mathrm{F}}$ is reversible (Figs. 6, 7), and channels can become operational/functional again in low $\left[\mathrm{Mg}^{2+}\right]_{\mathrm{I}}$, which suggests a stochastic release of $\mathrm{Mg}^{2+}$ from binding site(s). $\mathrm{Mg}^{2+}$ dependent modulation of $g_{\mathrm{j}}$ was not affected by phosphomimetic mutations of Cx36 at residues S110 and S293. We conclude that changes in phosphorylation at those positions are not necessary for the observed $\mathrm{Mg}^{2+}$-dependent modulation of $g_{\text {; }}$; however, we do not rule out the possibility that phosphorylation of $\mathrm{Cx} 36$ could modify coupling at different $\left[\mathrm{Mg}^{2+}\right]_{\mathrm{i}}$. In addition, the fact that asymmetry in $g_{\mathrm{j}}-V_{\mathrm{j}}$ dependence can be reversed in the same cell pair by exchanging pipettes with different $\left[\mathrm{Mg}^{2+}\right]_{\mathrm{p}}$ (Figs. 6, 7), and the fact that openings or closures can be consecutively induced by $V_{\mathrm{j}}$ steps of different polarity over relative short times using pipette solutions without ATP (Fig. 6A,D), strongly suggest that ATP-dependent post-translational modifications, such as phosphorylation, are not involved in the $\mathrm{Mg}^{2+}$-dependent modulation of Cx36 GJ channels. The inhibition of Cx36 GJ channels could also be induced by divalent cations other than $\mathrm{Mg}^{2+}$, and each divalent exhibited a different kinetics of $g_{j}$ decay (Fig. 9). These differences suggest that nonspecific screening of surface charges in the Cx36 protein or membrane phospholipids is unlikely to be a primary mechanism of $\mathrm{Mg}^{2+}$ dependent changes in $g_{j}$. Importantly, Cx36 GJ channels showed high sensitivity to $\left[\mathrm{Zn}^{2+}\right]_{\mathrm{i}}$, which plays an important role in CNS and pancreatic $\beta$-cells (Frederickson et al., 2000; Slepchenko and Li, 2012).

Finally, Cx36-containing electrical synapses between $\mathrm{Mes} V$ neurons showed similar, although smaller, $\mathrm{Mg}^{2+}$-dependent changes in cell-to-cell coupling compared with those observed in HeLa and N2A cells (Fig. 10C), suggesting that this mechanism could operate in the brain. The differences in the magnitude of the $\mathrm{Mg}^{2+}$ effect could be explained by differences between $\mathrm{MesV}$ neurons and heterologous expression systems, such as intrinsic buffer capacity, resting levels of $\left[\mathrm{Mg}^{2+}\right]_{\mathrm{i}}, \mathrm{Cx} 36$ levels of expression, and the presence of another $\mathrm{Cx}$ [based on residual coupling between MesV neurons in Cx36 knock-out mice (Curti et al., 2012)]. Nonetheless, electrical synapses between MesV neurons showed a clear and significant bidirectional modulation in $G_{\mathrm{j}}(\sim \pm 20 \%)$ dependent on $\left[\mathrm{Mg}^{2+}\right]_{\mathrm{i}}$ (Fig. 10D), which is consistent with results obtained in HeLa and N2A cells. Furthermore, the magnitude of changes in $\mathrm{Mes} V$ neurons is likely to be of physiological relevance, since longterm depression producing an equivalent reduction in $G_{\mathrm{j}}$ between neurons of the thalamic reticular nucleus has been suggested to produce changes in neuronal synchronization (Landisman and Connors, 2005).

In conclusion, the function of Cx36 GJ channels is strongly modulated by changes in $\left[\mathrm{Mg}^{2+}\right]_{\mathrm{i}}$. Effects of intracellular ATP on Cx36 GJs result, at least in part, from modulation of $\left[\mathrm{Mg}^{2+}\right]_{\mathrm{i}}$. We showed that (1) a substantial fraction of Cx36 GJ channels are inhibited even at resting levels of $\left[\mathrm{Mg}^{2+}\right]_{\mathrm{i}}(\sim 1 \mathrm{mM}) ;(2) \mathrm{Cx} 36 \mathrm{GJ}$ channels are permeable to $\mathrm{Mg}^{2+}$ ions, which can enter the channel and interact with pore-lining residues; and (3) the Cx36 GJ channel lumen contains a sensorial domain for divalent cations that upon binding induces a reduction in $P_{\mathrm{o}}$ and stabilization of a closed channel conformation. Thus, physiological conditions where cytosolic ATP decreases (e.g., increased neuronal activity during prolonged waking periods) or pathological conditions, such as hypoxia, ischemia or seizures, which lead to increased $\left[\mathrm{Mg}^{2+}\right]_{\mathrm{i}}$, might reduce neuronal synchronization via reduction 
in the strength of electrical synapses formed of Cx36 (Fig. 11). On the other hand, physiological conditions where cytosolic ATP increases (e.g., reduced neuronal activity during sleep period) or pathological conditions, such as traumatic brain injury, might induce an increase in Cx36-mediated gap junctional intercellular communication (GJIC) and neuronal synchronization (Fig. 11). In addition, increased synchronization of inhibitory neurons could lead to a reduction in synchronous activity of excitatory neurons. Modulation in the rates of binding or unbinding of $\mathrm{Mg}^{2+}$ through modification of the binding site(s) by physiological stimuli, such as post-translational modifications, lipophilic neuromodulators, and changes in $\mathrm{pH}_{\mathrm{i}}$, could be a source for fast control of Cx36-mediated GJIC and synchronization through electrical synapses.

\section{References}

Ainscow EK, Mirshamsi S, Tang T, Ashford ML, Rutter GA (2002) Dynamic imaging of free cytosolic ATP concentration during fuel sensing by rat hypothalamic neurones: evidence for ATP-independent control of ATP-sensitive $\mathrm{K}(+)$ channels. J Physiol 544:429-445. CrossRef Medline

Alev C, Urschel S, Sonntag S, Zoidl G, Fort AG, Höher T, Matsubara M, Willecke K, Spray DC, Dermietzel R (2008) The neuronal connexin36 interacts with and is phosphorylated by CaMKII in a way similar to CaMKII interaction with glutamate receptors. Proc Natl Acad Sci U S A 105:2096420969. CrossRef Medline

Al-Ubaidi MR, White TW, Ripps H, Poras I, Avner P, Gomès D, Bruzzone R (2000) Functional properties, developmental regulation, and chromosomal localization of murine connexin 36 , a gap-junctional protein expressed preferentially in retina and brain. J Neurosci Res 59:813-826. CrossRef Medline

Andrási E, Igaz S, Molnár Z, Makó S (2000) Disturbances of magnesium concentrations in various brain areas in Alzheimer's disease. Magnes Res 13:189-196. Medline

Barbiroli B, Martinelli P, Patuelli A, Lodi R, Iotti S, Cortelli P, Montagna P (1999) Phosphorus magnetic resonance spectroscopy in multiple system atrophy and Parkinson's disease. Mov Disord 14:430-435. CrossRef Medline

Bennett MV, Zukin RS (2004) Electrical coupling and neuronal synchronization in the mammalian brain. Neuron 41:495-511. CrossRef Medline

Bennett MVL (1966) Physiology of electrotonic junctions. Ann NY Acad Sci 37:509-539.

Bukauskas FF, Verselis VK (2004) Gap junction channel gating. Biochim Biophys Acta 1662:42-60. CrossRef Medline

Bukauskas FF, Weingart R (1994) Voltage-dependent gating of single gap junction channels in an insect cell line. Biophys J 67:613-625. CrossRef Medline

Bukauskas FF, Jordan K, Bukauskiene A, Bennett MV, Lampe PD, Laird DW, Verselis VK (2000) Clustering of connexin 43-enhanced green fluorescent protein gap junction channels and functional coupling in living cells. Proc Natl Acad Sci U S A 97:2556-2561. CrossRef Medline

Cernak I, Radosevic P, Malicevic Z, Savic J (1995) Experimental magnesium depletion in adult rabbits caused by blast overpressure. Magnes Res 8:249-259. Medline

Condorelli DF, Parenti R, Spinella F, Trovato Salinaro A, Belluardo N, Cardile V, Cicirata F (1998) Cloning of a new gap junction gene (Cx36) highly expressed in mammalian brain neurons. Eur J Neurosci 10:1202-1208. CrossRef Medline

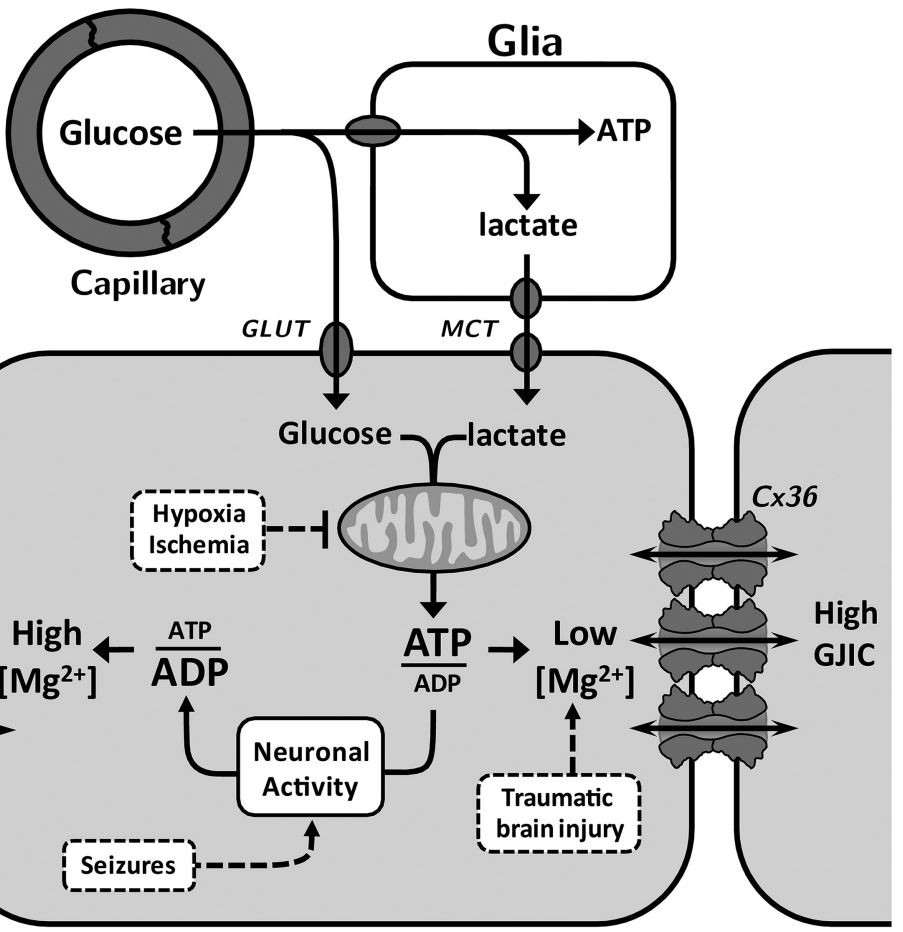

Neuron

Figure 11. Diagram illustrating relation between ATP/ADP ratio and $\left[\mathrm{Mg}^{2+}\right]_{i}$ and the effect on $C \times 36 \mathrm{GJ}$ channels. During sleep

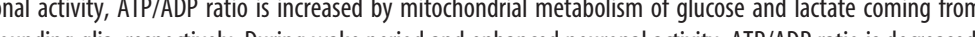
hypoxia, ischemia, and seizures may result in decreased GJIC, while traumatic brain injury may lead to increased GJIC. GLUT, glucose transporter; $M C T$, monocarboxylate transporter.

Connors BW, Long MA (2004) Electrical synapses in the mammalian brain. Annu Rev Neurosci 27:393-418. CrossRef Medline

Curti S, Hoge G, Nagy JI, Pereda AE (2012) Synergy between electrical coupling and membrane properties promotes strong synchronization of neurons of the mesencephalic trigeminal nucleus. J Neurosci 32:4341-4359. CrossRef Medline

Délèze J, Loewenstein WR (1976) Permeability of a cell junction during intracellular injection of divalent cations. J Membr Biol 28:71-86. CrossRef Medline

Dworak M, McCarley RW, Kim T, Kalinchuk AV, Basheer R (2010) Sleep and brain energy levels: ATP changes during sleep. J Neurosci 30:90079016. CrossRef Medline

Frederickson CJ, Suh SW, Silva D, Frederickson CJ,Thompson RB (2000) Importance of zinc in the central nervous system: the zinc-containing neuron. J Nutr 130:1471S-1483S. Medline

Grubbs RD (2002) Intracellular magnesium and magnesium buffering. Biometals 15:251-259. CrossRef Medline

Headrick JP, Willis RJ (1991) Cytosolic free magnesium in stimulated, hypoxic, and underperfused rat heart. J Mol Cell Cardiol 23:991-999. CrossRef Medline

Heath DL, Vink R (1996) Traumatic brain axonal injury produces sustained decline in intracellular free magnesium concentration. Brain Res 738:150-153. CrossRef Medline

Helpern JA, Vande Linde AM, Welch KM, Levine SR, Schultz LR, Ordidge RJ, Halvorson HR, Hugg JW (1993) Acute elevation and recovery of intracellular $[\mathrm{Mg} 2+]$ following human focal cerebral ischemia. Neurology 43:1577-1581. CrossRef Medline

Hinsberger AD, Williamson PC, Carr TJ, Stanley JA, Drost DJ, Densmore M, MacFabe GC, Montemurro DG (1997) Magnetic resonance imaging volumetric and phosphorus 31 magnetic resonance spectroscopy measurements in schizophrenia. J Psychiatry Neurosci 22:111-117. Medline

Kothmann WW, Massey SC, O’Brien J (2009) Dopamine-stimulated dephosphorylation of connexin 36 mediates AII amacrine cell uncoupling. J Neurosci 29:14903-14911. CrossRef Medline 
Landisman CE, Connors BW (2005) Long-term modulation of electrical synapses in the mammalian thalamus. Science 310:1809-1813. CrossRef Medline

Loewenstein WR (1967) Cell surface membranes in close contact. Role of calcium and magnesium ions. J Colloid Interface Sci 25:34-46. CrossRef Medline

Lüthi D, Günzel D, McGuigan JA (1999) Mg-ATP binding: its modification by spermine, the relevance to cytosolic $\mathrm{Mg} 2+$ buffering, changes in the intracellular ionized $\mathrm{Mg} 2+$ concentration and the estimation of $\mathrm{Mg} 2+$ by 31P-NMR. Exp Physiol 84:231-252. CrossRef Medline

Matsuda H, Kurata Y, Oka C, Matsuoka S, Noma A (2010) Magnesium gating of cardiac gap junction channels. Prog Biophys Mol Biol 103:102110. CrossRef Medline

Merlevede W, Vandenheede JR, Goris J, Yang SD (1984) Regulation of ATP-Mg-dependent protein phosphatase. Curr Top Cell Regul 23: 177-215. Medline

Mitropoulou G, Bruzzone R (2003) Modulation of perch connexin35 hemichannels by cyclic AMP requires a protein kinase A phosphorylation site. J Neurosci Res 72:147-157. CrossRef Medline

Moreno AP, Sáez JC, Fishman GI, Spray DC (1994) Human connexin43 gap junction channels. Regulation of unitary conductances by phosphorylation. Circ Res 74:1050-1057. CrossRef Medline

Moreno AP, Berthoud VM, Pérez-Palacios G, Pérez-Armendariz EM (2005) Biophysical evidence that connexin-36 forms functional gap junction channels between pancreatic mouse beta-cells. Am J Physiol Endocrinol Metab 288:E948-E956. Medline

Murphy E, Steenbergen C, Levy LA, Raju B, London RE (1989) Cytosolic free magnesium levels in ischemic rat heart. J Biol Chem 264:5622-5627. Medline

Nagy JI, Buss M, Daddona PE (1986) On the innervation of trigeminal mesencephalic primary afferent neurons by adenosine deaminase-containing projections from the hypothalamus in the rat. Neuroscience 17:141-156. CrossRef Medline

Noma A, Tsuboi N (1987) Dependence of junctional conductance on proton, calcium and magnesium ions in cardiac paired cells of guinea-pig. J Physiol 382:193-211. Medline

Ouyang X, Winbow VM, Patel LS, Burr GS, Mitchell CK, O’Brien J (2005) Protein kinase A mediates regulation of gap junctions containing connexin35 through a complex pathway. Brain Res Mol Brain Res 135:1-11. CrossRef Medline

Parker PR, Cruikshank SJ, Connors BW (2009) Stability of electrical coupling despite massive developmental changes of intrinsic neuronal physiology. J Neurosci 29:9761-9770. CrossRef Medline

Patel LS, Mitchell CK, Dubinsky WP, O’Brien J (2006) Regulation of gap junction coupling through the neuronal connexin $\mathrm{Cx} 35$ by nitric oxide and cGMP. Cell Commun Adhes 13:41-54. CrossRef Medline

Patton C, Thompson S, Epel D (2004) Some precautions in using chelators to buffer metals in biological solutions. Cell Calcium 35:427-431. CrossRef Medline

Paulauskas N, Pranevicius H, Mockus J, Bukauskas FF (2012) A stochastic 16-state model of voltage-gating of gap junction channels enclosing fast and slow gates. Biophys J 102 2471-2480.

Serre-Beinier V, Le Gurun S, Belluardo N, Trovato-Salinaro A, Charollais A, Haefliger JA, Condorelli DF, Meda P (2000) Cx36 preferentially connects beta-cells within pancreatic islets. Diabetes 49:727-734. CrossRef Medline

Slepchenko KG, Li YV (2012) Rising intracellular zinc by membrane depolarization and glucose in insulin-secreting clonal HIT-T15 beta cells. Exp Diabetes Res 2012:190309. CrossRef Medline

Söhl G, Degen J, Teubner B, Willecke K (1998) The murine gap junction gene connexin 36 is highly expressed in mouse retina and regulated during brain development. FEBS Lett 428:27-31. CrossRef Medline

Spray DC, Stern JH, Harris AL, Bennett MV (1982) Gap junctional conductance: comparison of sensitivities to $\mathrm{H}$ and $\mathrm{Ca}$ ions. Proc Natl Acad Sci U S A 79:441-445. CrossRef Medline

Srinivas M, Rozental R, Kojima T, Dermietzel R, Mehler M, Condorelli DF, Kessler JA, Spray DC (1999) Functional properties of channels formed by the neuronal gap junction protein connexin36. J Neurosci 19:9848-9855. Medline

Sugiura H, Toyama J, Tsuboi N, Kamiya K, Kodama I (1990) ATP directly affects junctional conductance between paired ventricular myocytes isolated from guinea pig heart. Circ Res 66:1095-1102. CrossRef Medline

Suzuki M, Nishina M, Endo M, Matsushita K, Tetsuka M, Shima K, Okuyama S (1997) Decrease in cerebral free magnesium concentration following closed head injury and effects of VA-045 in rats. Gen Pharmacol 28:119 121. CrossRef Medline

Teubner B, Degen J, Söhl G, Güldenagel M, Bukauskas FF, Trexler EB, Verselis VK, De Zeeuw CI, Lee CG, Kozak CA, Petrasch-Parwez E, Dermietzel R, Willecke K (2000) Functional expression of the murine connexin 36 gene coding for a neuron-specific gap junctional protein. J Membr Biol 176:249-262. CrossRef Medline

Teubner B, Odermatt B, Guldenagel M, Sohl G, Degen J, Bukauskas F, Kronengold J, Verselis VK, Jung YT, Kozak CA, Schilling K, Willecke K (2001) Functional expression of the new gap junction gene connexin 47 transcribed in mouse brain and spinal cord neurons. J Neurosci 21:1117-1126. Medline

Trexler EB, Bukauskas FF, Bennett MV, Bargiello TA, Verselis VK (1999) Rapid and direct effects of $\mathrm{pH}$ on connexins revealed by the connexin 46 hemichannel preparation. J Gen Physiol 113:721-742. CrossRef Medline

Vera B, Sánchez-Abarca LI, Bolaños JP, Medina JM (1996) Inhibition of astrocyte gap junctional communication by ATP depletion is reversed by calcium sequestration. FEBS Lett 392:225-228. CrossRef Medline

Verrecchia F, Duthe F, Duval S, Duchatelle I, Sarrouilhe D, Herve JC (1999) ATP counteracts the rundown of gap junctional channels of rat ventricular myocytes by promoting protein phosphorylation. J Physiol 516:447459. CrossRef Medline 